\title{
Anthrovision
}

Vaneasa Online Journal

1.2 | 2013

Varia

\section{African Lace: an industrial fabric connecting Austria and Nigeria}

Barbara Plankensteiner

\section{(2) OpenEdition \\ Journals}

Electronic version

URL: http://journals.openedition.org/anthrovision/679

DOI: 10.4000/anthrovision.679

ISSN: 2198-6754

\section{Publisher}

VANEASA - Visual Anthropology Network of European Association of Social Anthropologists

\section{Electronic reference}

Barbara Plankensteiner, «African Lace: an industrial fabric connecting Austria and Nigeria », Anthrovision [Online], 1.2 | 2013, Online since 02 August 2013, connection on 10 December 2020. URL : http://journals.openedition.org/anthrovision/679; DOI : https://doi.org/10.4000/anthrovision.679

This text was automatically generated on 10 December 2020 .

(c) Anthrovision 


\title{
African Lace: an industrial fabric connecting Austria and Nigeria
}

\author{
Barbara Plankensteiner
}

1 In Nigeria and the Nigerian Diaspora, attending a festive or official occasion without wearing "lace" is almost unthinkable, yet few people know how long this material has been an indispensable attribute of social life and how the tradition actually started. In fact it is approximately over fifty years that these colourful lace textiles define the appearance of Nigerians worldwide, and have become an intrinsic element of their festive clothing and fashion. The particular designs and qualities of these industrially produced fabrics for the West African market go back to the early 1960s and are a Nigerian-Austrian creation. Like the well-known wax prints produced for the African market first in Europe since the nineteenth century and later as well in Africa, that are today regarded as the African fabrics par excellence, the embroidery fabrics originating from the Austrian province of Vorarlberg are an expression of global intertwining and question conventional perceptions of tradition and authenticity. Yet, as well in Austria or Switzerland, it is largely unknown that an entire branch of the textile industry in these two countries survives primarily because of exports to West Africa.

2 With the term "lace" Nigerians actually refer to industrial embroideries. Non-experts easily confound certain qualities of industrial embroideries, specifically guipure (chemical lace) or eyelet embroidery, with real laces because they have a very similar appearance. The use of the term lace results from this confusion and its now a firmly established market denomination for all kinds of industrial embroideries, also of qualities that have no resemblance with real laces.

3 The denomination for these textiles in Nigeria indicates their origin while at the same time denoting a hallmark of excellence: most frequently they are referred to as "Swiss lace", which also implies a quality criterion, although the term is often used for materials that in fact originate from Austria. The term "Austrian lace" is also common and likewise stands for top quality. In international usage, the standard designation "African lace" implies that this product is something unmistakably African. 
This article tries to reconstruct how these textiles first emerged and developed over the decades. ${ }^{1}$ The history of industrial embroideries in Nigeria has so far remained unwritten, and the historical overview here is based on numerous interviews with time witnesses in Nigeria, Austria, and Switzerland. ${ }^{2}$ The overview makes no claim to completeness as far more actors were involved in this history of relations across continents than those whose accounts are summarized here. The research was part of a collaborative exhibition project that aimed to embrace the socio-cultural significance of Lace in Nigeria for the first time. ${ }^{3}$

View of exhibition installation at the Museum für Völkerkunde Wien

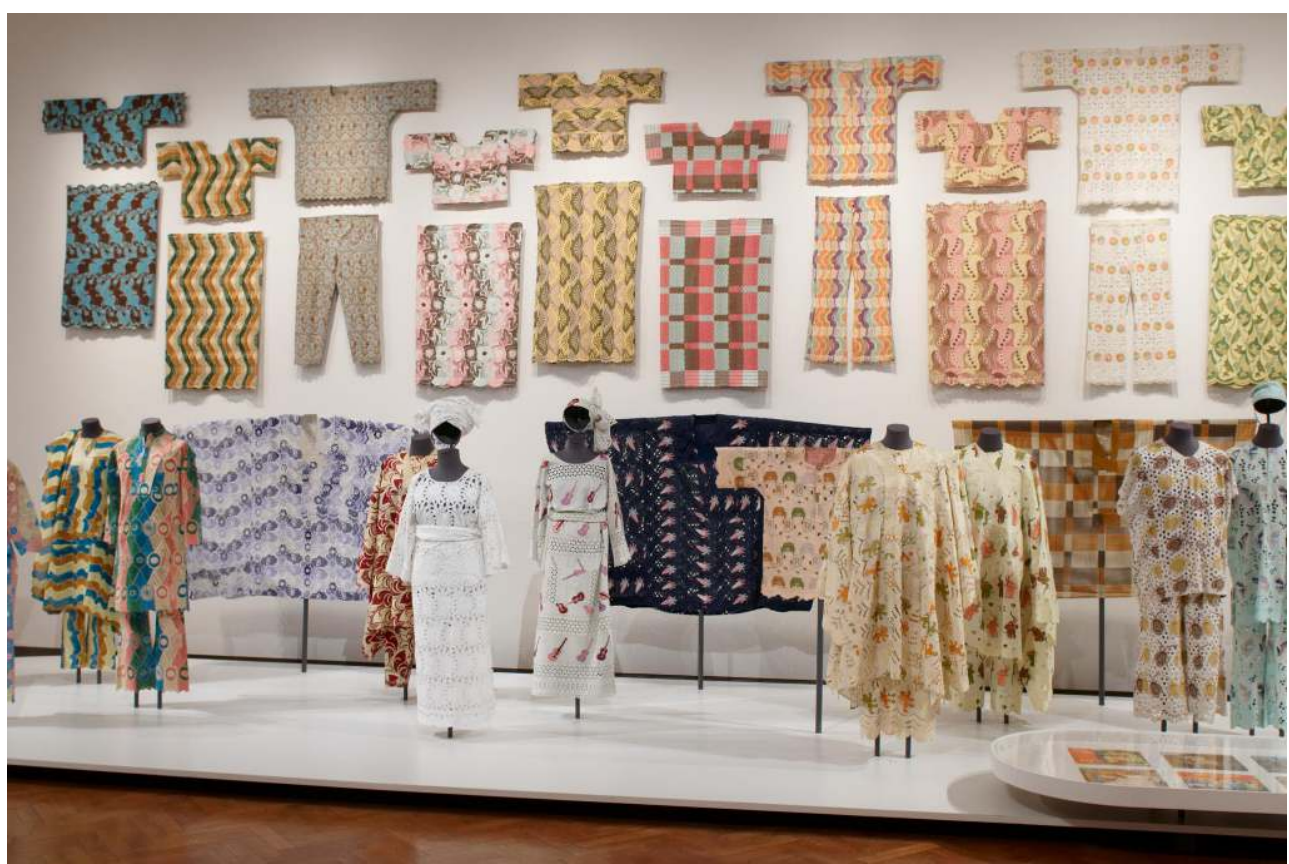

October 2010. Photo : Alex Rosoli.

KHM mit MVK und ÖTM. 
View of exhibition at Lagos National Museum

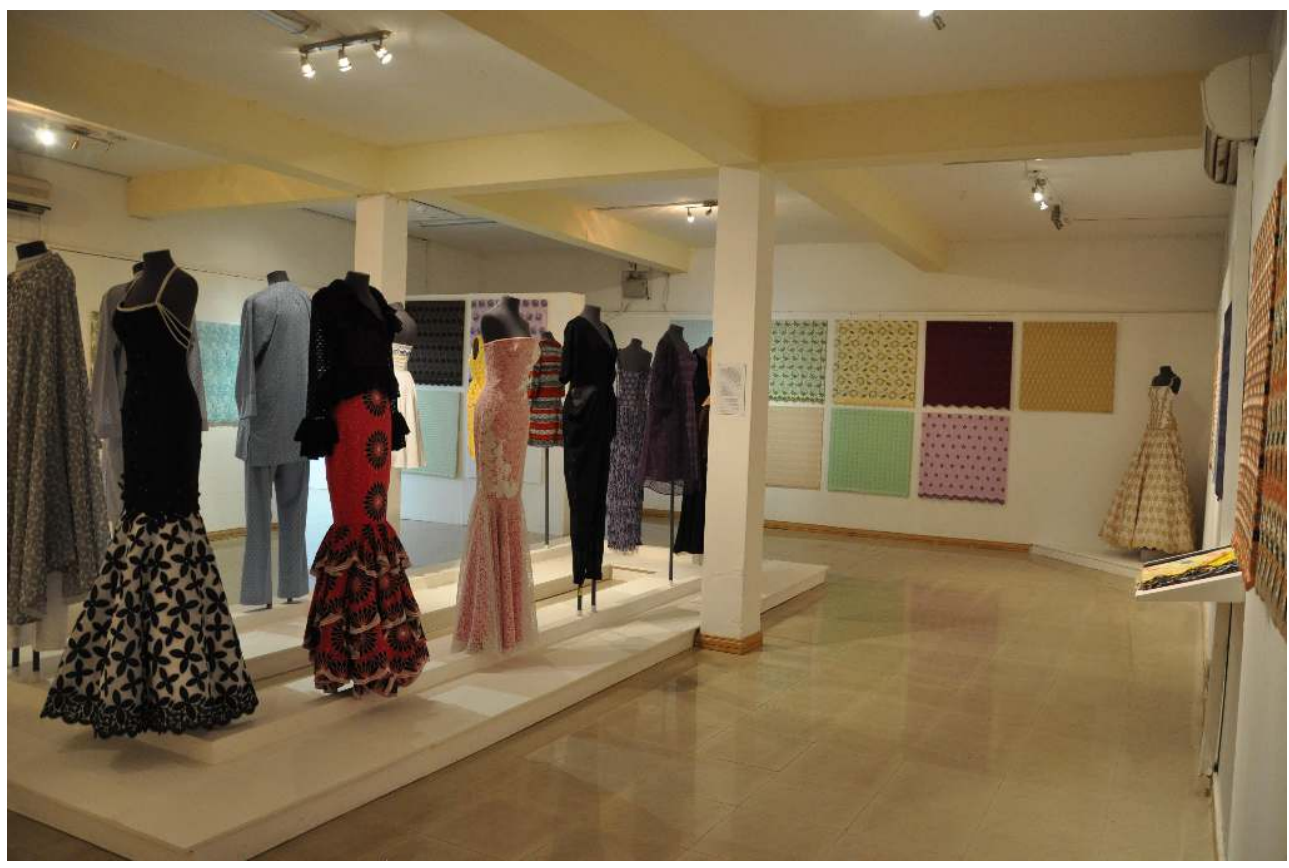

June 2011. Photo: Barbara Plankensteiner

\section{Guipuire embroidery fabric from the mid-1970is (detail of a lady's suit)}

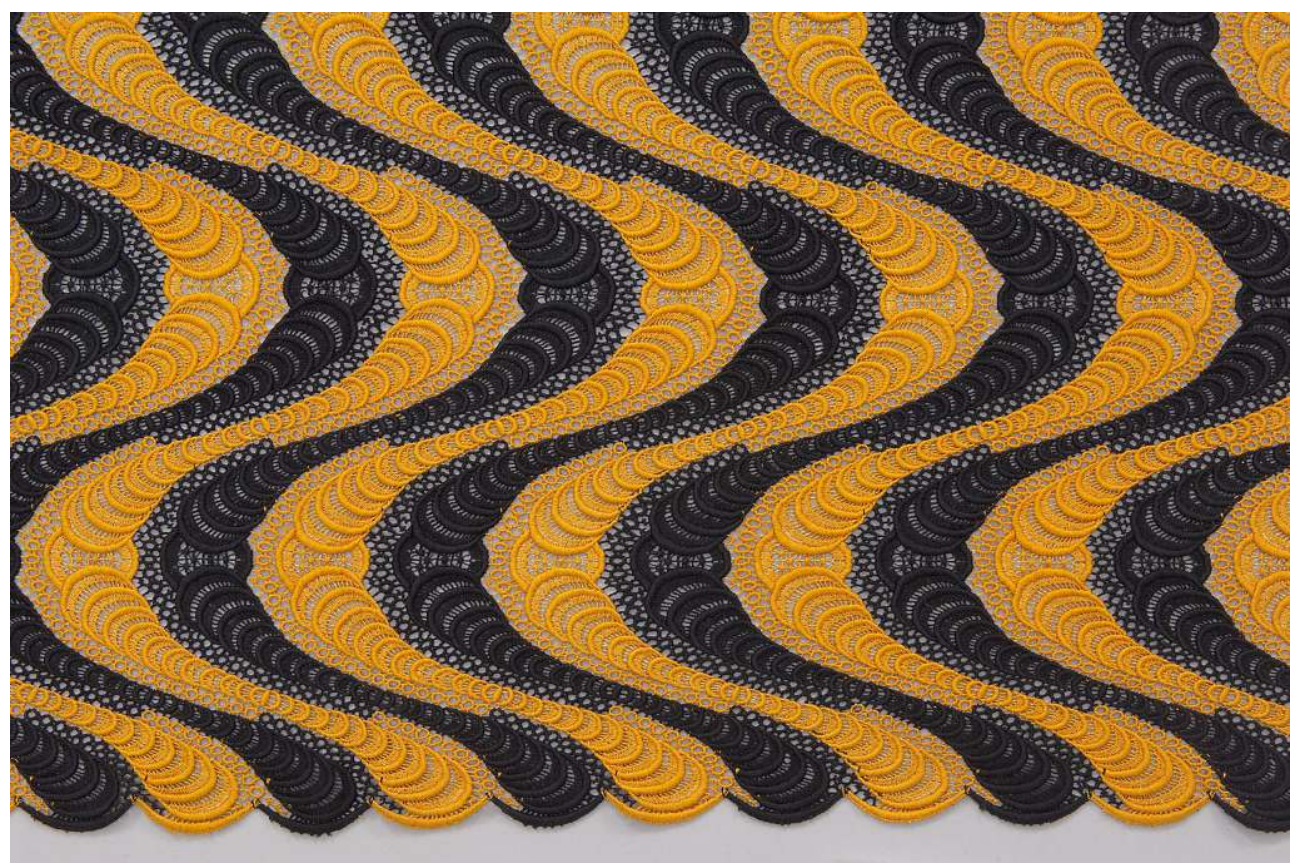

Museum für Völkerkunde Wien, Inv.No. 187.358. Photo: Alex Rosoli.

KHM mit MVK und ÖTM. 


\section{An Export-Oriented Textile Industry}

5 The historical beginning of the embroidery industry can be traced to the Swiss town of St Gallen where, during the mid-18th century, merchants inspired by Ottoman silver and gold embroidery initiated the production of hand-made embroideries on silk. A local shortage of embroiderers soon led to the training of peasant women from the Bregenzerwald area in neighbouring Austria, who worked part-time from home. The Lake Constance Region already had a long history of flax spinning and linen weaving going back to medieval times.

6 Though the first manually operated embroidery machines were in use around 1860, the real groundbreaking development for the embroidery industry came with the Swiss invention of the steam-powered shuttle embroidery machine (Schiffli machine) by Isaac Gröbli. The first embroidery factory in Lustenau on the Austrian border with Switzerland was founded in 1875 and by the turn of the century the embroidery industry had become the region's major employer and foreign exchange earner. Along with Switzerland and Saxony, Vorarlberg became one of Europe's three foremost centres of the embroidery industry. Increasing industrialisation did little to alter the basic structure of the embroidery industry. Even today, a significant part of production is out-sourced to small family enterprises (known as "wage embroiderers") operating one or two embroidery machines and under contract to larger embroidery companies.

Close-up of a fabric with allover embroidery emerging from on old-fashioned embroidery machine still in use

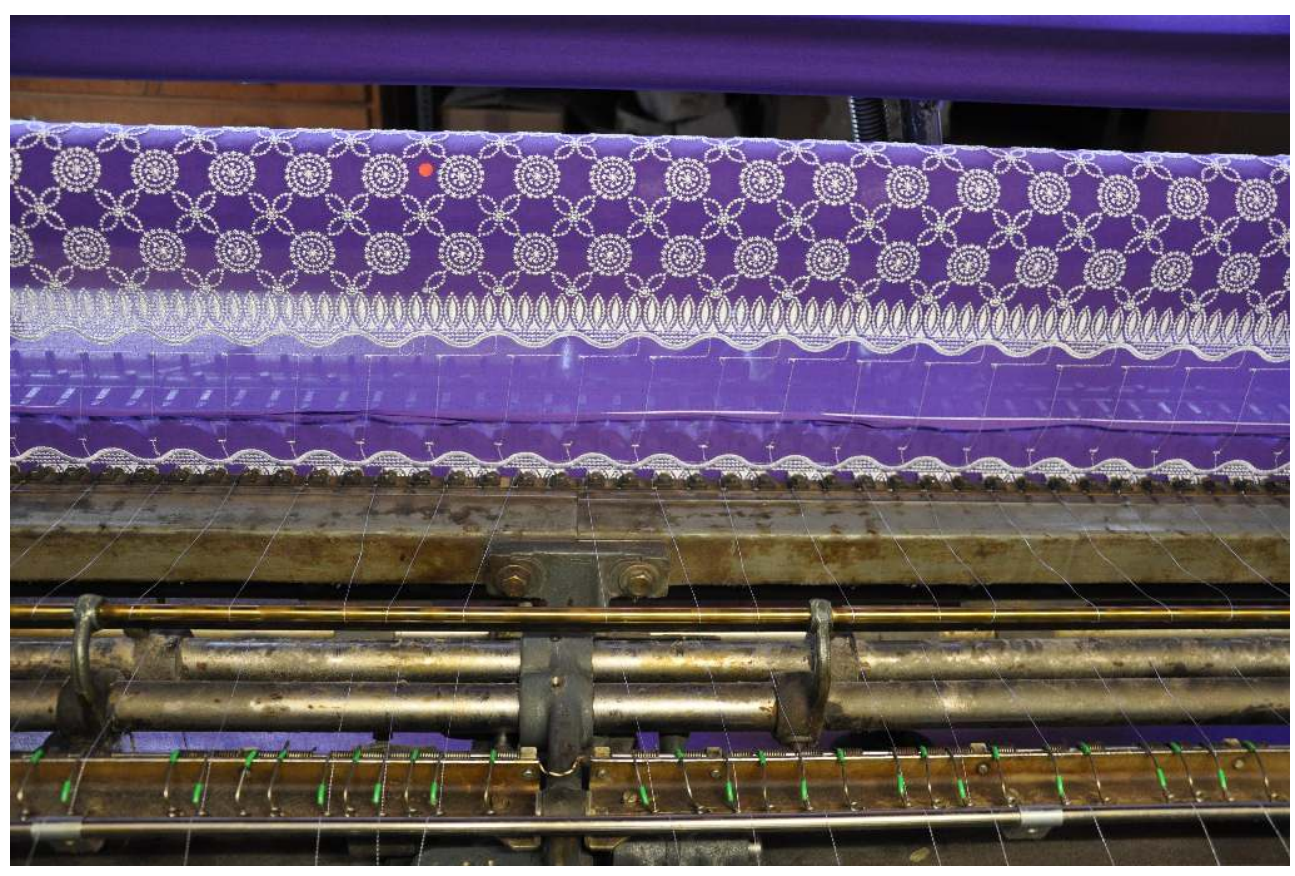

A red spot marks faults, which are then corrected on the hand embroidery machine. Ernst Bösch company, Lustenau. Photo: Barbara Plankensteiner 2010.

7 The embroidery industry in Lustenau in Austria flourished in the period from 1880 until about 1928, when almost all the town's residents earned their living in this trade (Fitz 1947). ${ }^{4}$ For the most part, embroiderers produced inlays and lace for ladies' underwear 
and for under- and over-garments. In the early 20th century, it was fashionable to wear white dresses made entirely of embroidered fabric; in the period from 1907 to 1910 blouses were often decorated with embroidery. Another standard product until 1928 were embroidered handkerchiefs.

At that time, the industry was already focused almost exclusively on exports. The target countries were mainly in Europe, with Great Britain and Germany the biggest buyers. Outside Europe, textiles were supplied to Egypt and Turkey. By about 1928, Austria was supplying as many as sixty-six countries, including many distant lands such as British India, Morocco, the Dutch East Indies, the USA, Argentina, British Africa, China, Japan, Mexico, Brazil, Cuba, and the British West Indies. Until the outbreak of the Second World War, the British West Indies, Great Britain, the Netherlands, French Morocco, and the Dutch East Indies were the largest markets; major clients in both Great Britain and the Netherlands were actually themselves export companies (Fitz 1947: 156). India purchased primarily dress fabrics embroidered with artificial silk, while demand in the North African market was for colourful fringed shawls and richly embroidered dress fabrics; embroidered curtains were sold to the Netherlands, and handkerchiefs, decorative cloths, tulle, and guipure lace to Great Britain (Fitz 1947: 157).

With the onset of the Great Depression, in about 1929 a major crisis also beset the embroidery industry, triggered by several factors. In around 1913, women's fashions in the USA and Europe switched to close-fitting garments, as a result of which demand for trimming lace - one of the industry's main products - declined. Furthermore, starting in 1917 cotton underwear was no longer decorated with embroidery. However, one of the chief reasons for the decline was the fact that from the First World War on, unembroidered artificial silk became fashionable for underwear, and the use of knitted fabrics in general became widespread. Accordingly Fitz stresses: "In summary it can be said that artificial silk (fabrics and knitted articles), colour weaving, and finally printed fabric are the three factors that caused fashion to turn its back on embroidery" (1947: 100). Another factor in the crisis was that many countries increased the import taxes levied on embroideries that were considered luxury goods, and therefore prices became problematically high. In the USA, for example, in 1922 customs duty rose from between 45 and 60 per cent to between 75 and 90 per cent, and in Japan in 1924 from 40 per cent to 100 per cent. In addition, in the interim an embroidery industry had established itself in the countries that had originally been major distribution areas. This was the case in the USA, France, and Italy. The biggest competition for Lustenau embroiderers at that time came from Switzerland, where embroidery had long been the most important export, ahead of watches, machinery, and silk. Saxony in Germany also had a significant embroidery industry; later on, competition came from the USA, Japan, Italy, and France (Fitz 1947: 177).

With the annexation of Austria by Nazi Germany, foreign markets for Vorarlberg embroidery declined, and after the war the industry was hit hard again, this time by the shortage of raw materials. In the 1950s, the embroiderers went to great lengths to regain their markets and above all to identify new ones.

\section{The Beginnings of Austrian Lace Exports to Nigeria}

11 The history of embroidered textiles in Nigeria dates back to the early 1960s. Prior to that, probably from the 1930s on, embroideries were used by women in Nigeria for white 
blouses that they wore with wraparound skirts of locally woven fabrics. These textiles were imported by British, German, Dutch, Lebanese, or Indian trading houses in coastal cities and sold through retailers across the country. Textiles from Vorarlberg probably already figured among their assortment, as large quantities were sold to export companies in Great Britain and the Netherlands. According to Heinz Hundertpfund, ${ }^{5}$ certain Austrian textile companies were already supplying Nigeria directly before the 1960s. The largest were the Getzner textile factory in Bludenz (manufacturer of cotton damask textiles), the F.M. Hämmerle textile factory in Dornbirn, and Jenny \& Schindler in Tyrol, both of whom produced structured cotton fabrics. To this day, Getzner is the biggest producer of fine damask textiles for West Africa; their main markets are Mauritania, Mali, and Senegal, but they also supply large quantities of fabrics to the Islamic North of Nigeria.

12 A number of factors contributed to the development of the market for embroideries in Nigeria. Nigerian independence in 1960 not only favoured the establishment of a wealthy middle class, but also spawned other developments that facilitated international business contacts. Nigerian merchants increasingly took the initiative to circumvent the commercial agencies established during the colonial era from which they had until then bought their goods, preferring to establish direct contact with producers in Europe with a view to earning greater profits themselves. The opening of the Austrian embassy in 1962/63 with a trade delegation played a decisive role in this development, as for the first 10 years the position was occupied by an enthusiastic man from Vorarlberg. Trade delegate Heinz Hundertpfund had observed the popularity of white lace for blouses in Nigeria and had alerted embroiderers in his home region to this trend. Furthermore, the introduction by Lufthansa and Swiss Air of direct flights to Lagos in the early 1960s simplified travel.

13 There are two different oral traditions about the first Vorarlberg embroiderers to travel to Nigeria and lay the foundation of this trade relationship, which has now endured for more than 50 years. Hundertpfund remembers Josef Fenkart from Hohenems, whom he met in person in Lagos in 1962, as the first embroiderer from Vorarlberg. Others believe that it was Kurt Nachbauer from the Lustima company who blazed the trail in Nigeria (Murorunkwere 2002: 41). Lustima did not themselves produce but rather sold goods from various Vorarlberg factories, who made lace on commission for them. As some Nigerian merchant dynasties remember it, the name Lustima became known as one of the first Austrian companies to establish direct trade contacts in Lagos. For example, Debo Adekoya, who is considered the first large-scale Nigerian importer of Austrian embroideries, purchased goods from Lustima in the early 1960s and had travelled to Lustenau. He took over the company Crumpsall Enterprises on Lagos Island from his father, who had imported shoes from Manchester for the elite of Lagos. Adekoya himself traded in textiles and brought back samples of industrial embroideries from a trade fair in Great Britain after noticing the product there. ${ }^{6}$

14 At all events, there is no doubt that Vorarlberg embroiderers looked to Africa in the 1960s to find new markets. In the 1950s, large volumes of embroidered flounces were sold to Venezuela; however, as these exports declined, companies tried to gain a stronger foothold in Sudan, where "embroidered saris" - light cotton voile fabrics with minimal embroidery - were a much requested merchandise. ${ }^{7}$ At the same time, companies were looking for other markets and reached Nigeria, where the Austrian trade representation now provided support services. 

along Kosoko Street on Lagos Island, which was at the time the centre of the textile market, was decisive for their success. With this important step, they succeeded in eliminating intermediaries and rapidly boosting direct trade. However, this direct contact also involved a larger risk for the Vorarlberg exporters, because until then European producers had delivered exclusively to local trading houses who guaranteed payment. Direct contact offered the advantage of gaining decisive insight into the interests, quality expectations, and colour preferences of the Nigerian customers; furthermore it generated awareness of the importance of adhering to delivery deadlines, as the textiles were normally ordered for specific festive occasions and were no longer needed if the agreed delivery date was not met. These personal business contacts also resulted in mutual trust and counter-visits of the Nigerian business associates to Austria. ${ }^{8}$ The same principles characterize business relations to this day; some contacts date back more than 40 years, and in the family-owned businesses in Lustenau as well as in Nigeria, the next generation has since taken over the business and is continuing the collaboration.

Once initial contacts had been made, between 1966 and 1972 the trade developed very promisingly. Both in Lagos and in Lustenau, news had spread about supply and demand, and both sides actively sought direct contacts. An increasing number of Lustenau companies sent their sales representatives to Lagos, and buyers in Nigeria tried to locate production facilities themselves. The dynamics of this process were comparable on both sides. At first it was wholesalers in Nigeria and large-scale producers in Austria who dominated the transnational business, but in the heyday of the trade, these groups gradually expanded on both sides. In Lustenau it resulted in increasing specialization in the so-called "Africa business" and the founding of a large number of specialized production companies; in Nigeria, more and more businesswomen started making contact with Lustenau themselves and visiting the town.

In addition to Lustima, the first Austrian companies to enter the business were Hagen KG, owned by Edwin Hagen, also known as "Cash Papa"; Ernst Grabherr and Hofer KG represented by Oswald Brunner; Josef Blaser for Erich Bösch; Ernst Hofer for Oskar Hämmerle, all situated in Lustenau, and Franz Mäser in Dornbirn. ${ }^{9}$

One of the first importers was Chief Modupe Asabi Obebe from Abeokuta, the Iyaloja of Egbaland, also called Mama Tutu. The cousin of later president Olusegun Obasanjo, she was a wealthy trader on Kosoko Street on Lagos Island and owner of Ebun Oluwa Stores, ${ }^{10}$ and was quickly identified by the Lustenau embroiderers as the perfect, financially strong business associate. She vigorously defended her position as market leader against the competition.

19 Later, in the 1970s and 1980s, Prince Shafi Mobolaji Shitu, ${ }^{11}$ the Baba Adinni and ruling Olowu of Aiyepe, was one of the biggest importers of Austrian lace and later founded a factory together with an Austrian partner. In the mid-1960s he had noticed that an importer in Lagos who stocked goods from Lustima was very successful. Shitu and his brother Suleiman were already well established in the textile business, with their main store in the so-called Gutter on Lagos Island. They imported stiff brocades, called damask in Nigeria, primarily from Germany, but also Guinea brocade (i.e., plain cotton damask), and carried an assortment of whitework embroideries that they had been purchasing from Italy since 1954. The Italian fabrics were of lower quality than the Austrian, for which a better base material was used..$^{12}$ Prince Shitu did some investigating; he travelled to Zurich for the first time in 1966 and from there via St Gallen to Dornbirn, where two 
Sudanese businessmen whom he met at the hotel put him in touch with the Ernst Grabherr factory. In St Gallen at the company Filtex, which was not yet involved in the trade with Africa, he could not find suitable merchandise; but thereafter he was successful in Lustenau. He started importing unicolour Austrian embroideries and the following year purchased multicoloured versions that were produced following his suggestion. Prince Shitu gradually expanded his business contacts in Lustenau and its environs and purchased goods from various companies, visiting them regularly and developing collections together with them.

Another major importer in Lagos, Chief Temitenjo Mercy Owolana ${ }^{13}$ the Iyaloja of Remo, started importing embroideries in about 1970. She did this through London, where she also unknowingly purchased Austrian goods and took them to Nigeria. The textiles sold extremely well, and when she detected the country of origin on a label, she was told about the town of Lustenau. She travelled there in 1971, obtaining a visa in London and flying from there to Vienna. Once there, she realized that Lustenau was located at the other end of the country. She still collaborates with Oskar Hämmerle in Lustenau, the first company from which she purchased goods, and is a major customer for several other companies. However, her entry into the Lustenau production network was not entirely without friction, as established importers were keen to maintain their leading position in the market and above all protect the exclusivity of their products. After establishing contact with Lustenau, Owolana ran into problems with her competitor Obebe, who even intervened with the Austrian authorities in Lagos, alleging she had copied colours. Competition between Lustenau embroiderers was high, and both sides were and are careful to keep trade secrets even from their colleagues in order to keep their position in the market.

In the above-mentioned Lustenau companies who entered the "Africa business" on a large scale in the mid-1960s, employees or managers were assigned to this particular trade, and it developed into a specialization. Experienced employees normally remained in the field throughout their career and could apply their knowledge working for different companies. Some of the trailblazers who had travelled to Nigeria early on are still in the business; others have turned to new fields of activity.

Oswald Brunner, now the owner of a bookstore chain, was one of the most successful salesmen of Austrian embroideries in the 1960s and 1970s. Working for Hofer KG, where he was General Manager for many years, he travelled for nearly two decades to Nigeria and played a decisive role in the development and expansion of the market. His earliest contact with the local textile trade was through the Belgian trading company Comptoir Commercial, which brought him his first big orders. He visited Nigeria for the first time in 1967 and introduced his company's products there. His journey took him all the way across Africa: he flew via Cairo to Khartoum, then to Luanda in Angola, from where he planned to fly on to Lagos. To do that, he first had to go to Johannesburg, reaching Accra in Ghana and from there Lagos; from there he was finally taken to Ibadan by the Belgian import firm that secured him his first local customers. However, he soon established direct contacts himself. His biggest customer, with whom he maintained close contact, was Mrs Obebe. Her key business associates from Lustenau were present when she was invested with the title Iyaloja in Abeokuta at the beginning of 1979. Oswald Brunner visited Nigeria for the last time in 1983 and soon after that he went into a different business. In the era of the greatest demand in the late 1970s, he sometimes flew to Lagos twice a week. He once took fifty-six suitcases of Austrian lace with him on the plane to 
Kano so that he could deliver the goods made for a big order from his major customer Olanrewajo on time.

Josef Blaser, generally known as Chief Blaser after having been honoured with a chief title in Lagos, was responsible for the Nigeria business for several companies in Lustenau. In 1967 he travelled to West Africa for the first time on behalf of the company Erich Bösch, for whom he had been working since 1958. He was bound for Accra in Ghana, where he wanted to show embroidered borders that were imported from Lustenau by Indian trading houses. On the way to Accra, the plane stopped over in Lagos, where he took the opportunity to meet the trade delegate Hundertpfund. He initially offered borders in Lagos too, but he noticed embroideries on sale at the Kingsway - a British trading house that probably originated from Switzerland. He made contacts in the textile market on Lagos Island, which initially proved difficult because coordinating payment and order placement was problematic with the small retailers, who often could not read or write. It was only over time that he was able to build up connections with wholesalers. From 1973 on, the time of the trade boom, he was employed by another company - Platter. He has now worked for more than 20 years for Riedesser, but has not travelled to Nigeria himself since 2004. Initially he usually stayed in Nigeria for an average of a week, during which time he spent two days in Ibadan visiting major customers on Lebanon Street.

Karl Hagspiel, known as Charlie in the Austrian lace business, worked for 25 years for his uncle, Ernst Grabherr, starting in 1959, and travelled to Nigeria for the first time in 1969. Initially Grabherr's biggest customers were the Shitu brothers and Mrs Obebe. Hagspiel lived for 4 years in Nigeria and worked at the Nigerwest Austrian embroideries factory established in 1974 by Grabherr and his Nigerian associate Dr Akinbyi in Agege, Lagos. When he returned to Austria, he managed his own company in Lustenau, which inbetween he ran as a wage embroiderer carrying out commission orders.

In the 1970s, when business was flourishing, other lace companies in Vorarlberg also established production facilities in Nigeria. They did this together with Nigerian partners, who were typically also wholesale importers. One of the best-known companies was ANEF - Austro-Nigerian Embroidery Factories Ltd - in Aiyepe in the Ijebu region, established in 1972 by the Shitu brothers and Franz Mäser. Prince Shitu managed the successful company after which a certain type of lace, "Aiyepe Lace", was named, until the late 1990s, when he had to close the factory due to infrastructural problems that affected the entire textile industry in Nigeria. ${ }^{14}$ The factors responsible for this crisis in the textile industry and the closure of numerous factories in Nigeria were cheap, smuggled goods, high production costs caused by difficulties obtaining raw materials, and high energy costs. A lack of political will to support the industry was a further factor. ${ }^{15}$

Another well-known production company was Shokas (Shote \& Kasim) Industries, also located in the Ijebu region. The factory Novelty Embroideries was set up for the Lustenau embroidery firm of Platter by their Nigeria expert Blaser together with Alhaja Agberu Agba. In all there existed twenty embroidery factories in Nigeria with a total of 494 machines, located in Lagos and the Ijebu region.

The only embroidery plant that has survived to this day is Supreme Lace (formerly Anlam Ltd) in the Ikeja area of Lagos. The factory is managed by Dele Fateayi-Williams and Rudi Bösch of Lustenau, who has lived and worked in Nigeria since 1979. The son of a family in the embroidery business, he studied economics in Switzerland and travelled to Nigeria for the first time in 1972. His father, Anton Bösch, and his partner, Robert König, had founded a factory in Nigeria as well, but it closed before long. 
One of the largest and well-known African lace producers in Lustenau, HOH HoferHecht Embroideries, only entered the Nigerian market in the mid-1970s; however, they had been supplying embroidered textiles to Morocco for years, and textiles from their production were available on the Nigerian market before then, as they were distributed by Lustima. The family business, which supplies the major fashion houses in Europe, had specialized in embroidered organza, which they introduced to the Nigerian market in 1975. Here again, Chief Obebe was the first importer. General Manager Werner Berlinger remembers his first major order for expensive, hand-cut organza products studded with Swarovski crystals: due to lack of knowledge of the market, the double-sided scallops so important for the Nigerian marked had been omitted, and he had tremendous difficulty selling the product. ${ }^{16}$

\section{Nigerianization and Change in the Market Structure}

In the early days, until about the end of the 1970s, ten to fifteen Lustenau companies dominated the Nigerian market. On the Nigerian side, there were a limited number of major importers, for whom certain patterns had to be embroidered exclusively. Petty traders purchased their goods from these companies and not directly from the Austrians. Between 1978 and 1985, however, the market structure changed: increasingly, small-scale traders travelled to Austria and started importing embroideries themselves. During this period, when lace production was also experiencing a heyday, more and more small producers in Lustenau and the surrounding area entered the business. This trend was linked to political events in Nigeria and fuelled by a series of government decrees aimed at increasing Nigerian participation in the national industry; one measure taken to this end was the imposition of import restrictions.

After the devastating Biafran War in 1967-70 that threatened to break the country, from 1973 on Nigeria experienced an unparalleled economic upswing thanks to petroleum exports, and it saw a period of affluence and national optimism due to the oil boom that lasted until 1979. With this focus on the oil business, from which the state reaped huge revenues, local industry and agriculture were neglected, and the increase in imports was disproportionately large (Falola and Heaton 2008). With more money available, the population's consumer behaviour changed, and more and more imported luxury goods were bought.

In 1972 and 1977, two decrees were brought into effect limiting foreign ownership in local enterprises to a certain maximum percentage, depending on the size of the company, to secure Nigerian participation (Beveridge 1991). The military government under General Yakubu Gowon (1970-75) issued the first decree to reduce the preponderance of foreign interests in the Nigerian economy. This policy of "Nigerianization" was continued by Mohammed Murtala after Gowon's overthrow and after the murder of Murtala in February 1976 by General Olusegun Obasanjo. In the context of these so-called "Indigenization Decrees" Obasanjo finally banned the import of industrial embroidery textiles. The ban was intended to strengthen local industry and preserve the country's foreign exchange reserves. ${ }^{17}$ The first import restrictions took effect on 1 April 1976, and a general ban on imports was issued in April 1977. ${ }^{18}$ However, the import ban did not prevent Austrian lace from entering the country. The embroidery companies continued to deliver despite the ban; the profit margin was so high that eventual impounding of goods was not a problem as the business could easily absorb occasional losses. Only after 
the reinforcement of controls with the complete ban on imports did the producers ship to the neighbouring Republic of Benin, shifting the risk to importers. ${ }^{19}$

The 1977 complete ban on imports caused a "Nigeria shock" among Austrian companies, as at that time more than 90 per cent of Austrian embroidery exports were bound for the West African country, and exporters feared a radical slump in their industry. However, other distribution channels were soon found. The question posed in Austria's media on how the industry could secure its continued existence was answered by the then president of the Embroiderers' Association: “We have no intention of exposing our secrets to the competition." ${ }^{20}$ At all events, export statistics showed clearly how the business was rescued, as Austrian embroidery exports to the neighbouring country, the Republic of Benin, suddenly rose dramatically.

In Austria, the disrupted relations with Nigeria suddenly became a matter of interest, and the media reported extensively on the situation. Whereas some reports commented ironically on the reactions in Austrian politics others sought to provide a critical examination of the facts; another reported at length on the events, but in flippant language, with an illustration showing a stereotypical and denigrating caricature of the Nigerian customers. ${ }^{21}$ The headlines alone, "Embroiderers have lost the thread" and "Entwined in black market business", revealed the degree of irony that characterized all the reporting. Both the Vorarlberg producers and Nigerians as the purchasers are portrayed here as actors in a curious, exotic comedy rather than as conflicting parties in the midst of a serious economic crisis in international relations.

The Austrian embroidery industry put pressure on the Austrian government to push for the abolition of the import ban and restoration of a balance between exports from and imports to Nigeria, as they considered the low volume of Nigerian petroleum bought from Austria and the import ban on African lace to be directly connected. First and foremost the ban affected Austrian producers, who at the time dominated this market. The situation escalated in summer 1977 when, shortly after the imposition of the complete ban on imports, the two Austrians Karl Hagspiel and Heinz Mayer were arrested in Nigeria on suspicion of smuggling foreign currency.

35 Austria sought to solve the problems of Austrian embroidery exports at top political levels and to conclude a "cooperation agreement" with Nigeria that would have secured greater imports of Nigerian crude oil, but also promised more training for Nigerians in Austria. At the same time, efforts were made to obtain the release of the two Austrians imprisoned in Nigeria.22 While Mayer, brother-in-law of then Agriculture Minister Günther Haiden, was released after a few months and declared innocent of the foreign currency offence, Hagspiel remained in custody; after forty-four days' confinement in a dark cell in Lagos, he spent a year in prison in Abeokuta. The fact that he knew General Obasanjo in person - whose former girlfriend Sofowora was herself a major importer and dealer in embroideries - did not benefit him in the least.

After the announcement of the total ban on the import of embroideries, Nigeria instituted draconian punishments. Armed smugglers were threatened with the death penalty, smugglers caught in the act could reckon on 5 years in prison, and those found in possession of smuggled goods could be imprisoned for a year unless they proved that the goods had entered the country legally. ${ }^{23}$ In Nigeria too, reactions to the import ban on embroideries were vehement and had a high level of coverage in the press, but the reporting differed in content from that in Austria. Initially lace confiscated at the airport could be purchased at low prices and the revenue went to the state, but soon it was 
considered more appropriate to burn the smuggled goods publicly. This practice was documented with series of photographs in the newspapers and became a topic of heated debate being commented on vividly such as in an article titled "Wonyosi Bonfire". ${ }^{24}$

At the same time, efforts were made to pacify outraged lace lovers by referring to the local textile industry, with a promise of improvements in quality. New factories pledged to satisfy the increasing demand for domestic products. For example, Alhaji Garba Inuwa founded the Magwan Textile Company in Kano in 1977, with Lothar Fenkart from Vorarlberg holding a 40 per cent share; they announced plans to produce 2,000 metres of light embroidery fabrics a day, and even though nearly reaching Austrian quality, it would be priced well below imported lace. ${ }^{25}$ However, one of the difficulties for the local embroidery industry was that raw materials had to be imported, and some of them were also affected by the import ban.

Another reaction in Nigeria was condemnation of the excessive waste of purchasing disproportionately expensive imported lace, as well as other luxury products. This was widely discussed in the newspapers:

"It is one thing for government to make laws that forbid excesses like Wonyosi and Champagne. It is, however, another matter for every individual to feel a genuine sense of commitment to keeping these laws. For the evils that we fight are far beyond the laces, the naira spraying parties and the gold trinket contests. These excesses themselves reflect the downward trend in the lives of people who have engaged in trading in their self-respect and mental stability for cheap gaudy and perishable articles." ${ }^{26}$

In addition to luxury textiles, champagne, specific types of wine and certain car brands were subject to the import ban. Spraying developed as a phenomenon of modern Nigerian society and became common, for example, at weddings or wherever Juju music was played: the bridal couple or the musicians are praised by being showered in an almost ceremonial fashion with banknotes; the prime objective is to take centre stage as "donor" of the highest amount. Spraying therefore also serves as self-dramatization (Bender 2007: 323). The debate regarding excess at that time centred on luxurious embroideries called Wonyosi, characterized by hand-cut perforations, applications, and Swarovski crystals attached to the fabric. Wonyosi became a symbol and epitome of the wastefulness of a segment of the society that had become affluent as a result of the oil boom. A class that Wole Soyinka sharply condemned in his socio-critical Opera Wonyosi.

Criticism of the use of imported luxury items and the indigenization campaign in the economic field were accompanied in the cultural sphere by a strong emphasis on national cultural values, culminating in Nigeria's staging of the Second World Black and African Festival of Arts and Culture, called FESTAC, in 1977. It aimed to emancipate Nigeria from former colonial influences and feature the country's own, self-determined modern culture by a return to its own roots:

"In effect, colonial culture was nationalized and indigenized by FESTAC - revalued as Nigerian and projected back into a pre-colonial past. If FESTAC's work of cultural production concealed the material relations of Nigeria's oil prosperity, it also congealed an entire colonial heritage under the sign of its displacement and disavowal; that is through the explicit project of cultural recuperation as a way of exorcising the ghosts of colonial domination." (Apter 2005: 16)

41 This attitude found its expression in the visual and performing arts, in literature, music and also in fashion. 
In the realm of fashion, efforts were made to refocus on locally woven textiles as a counterpoint to the universally popular lace fabrics, and aso oke production reached new heights. Politicians and other people in the public eye increasingly appeared in handwoven textiles. Fashion designers made a commitment to promote Nigeria's textile traditions and developed models using hand-woven strip cloth or the resist-dye adire textiles. Furthermore, the late 1970s saw a wave of innovations in the production of aso oke textiles, which were now available in a wide variety of colours and with the introduction of imported lurex yarn offered an attractive, modern alternative to the embroideries. This so-called shain-shain variant became a huge success, and aso oke textiles with decorative openwork (eleya) were in high demand. The process was later intensified by economic adversity, as purchasing power in Nigeria declined, but was equally advanced by patriotic ideals: "Taken up as fashionable dress by an urban, educated elite, these cloths are worn at traditional ceremonies as an expression of nationalistic-Africanist sentiments" (Renne 1997: 774).

\section{Men's shain shain suit}

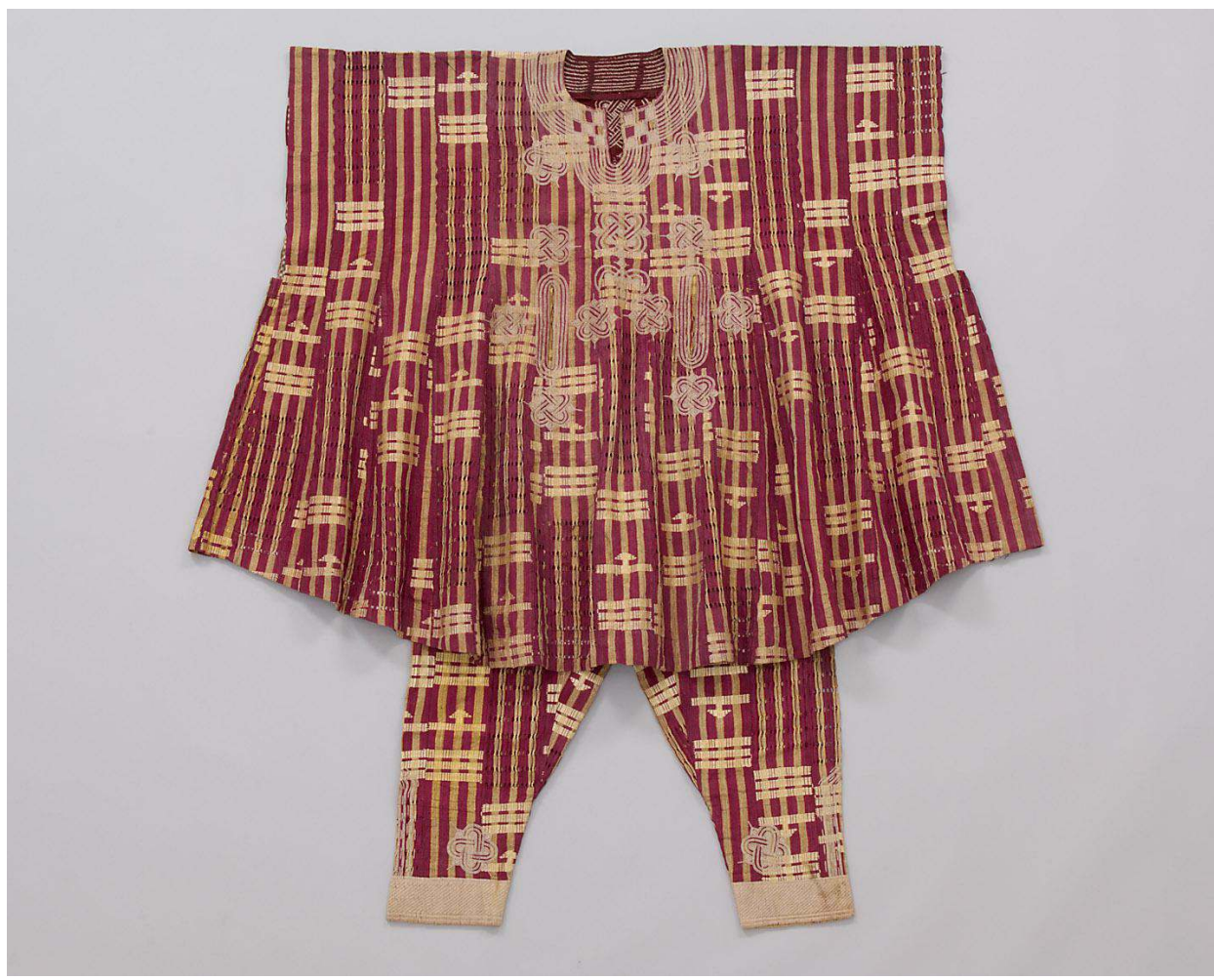

Southwestern Nigeria, late 1970s. Handwoven narrow-strip cloth in cotton and lurex yarn. Dansiki shirt: L $103 \mathrm{~cm}$, kembe three-quarter length pants: L: $96 \mathrm{~cm}$. Museum für Völkerkunde Wien, Inv. No. 188.522. Photo: Alex Rosoli.

KHM mit MVK und ÖTM. 


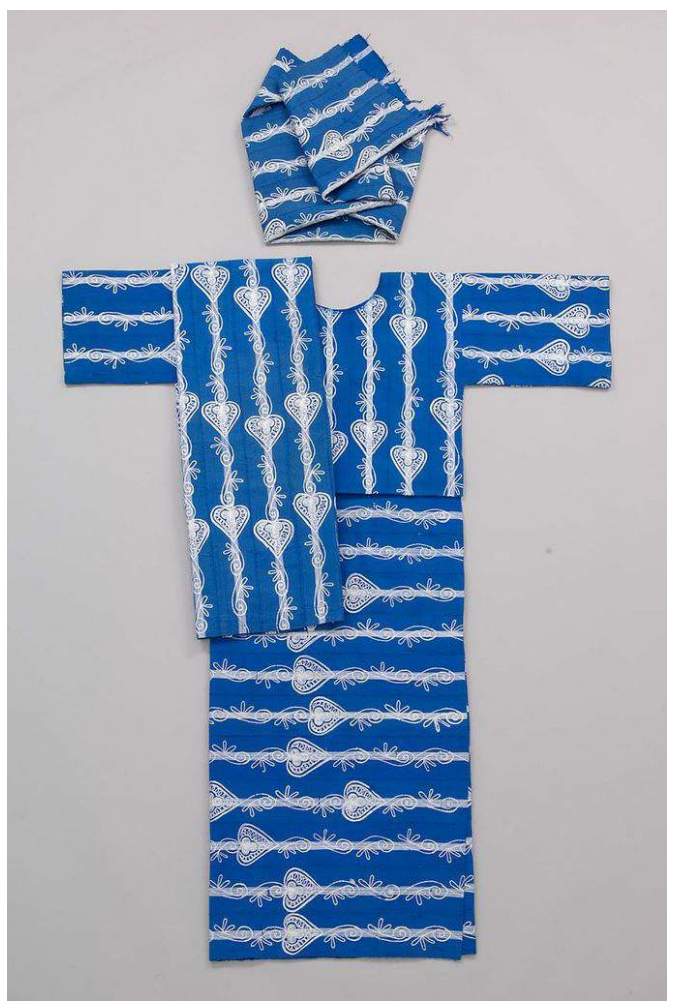

Southwestern Nigeria, late 1970s. The pieces of the ensemble are composed of a differing number of cotton narrow-strip decorated by machine in chain stitch with cotton-lurex yarn. Iro wrapper: L. 150 cm, buba blouse: L. $59.5 \mathrm{~cm}$, iborun shoulder cloth: W: $91 \mathrm{~cm}$, gele head tie: W. $69 \mathrm{~cm}$. Museum für Völkerkunde Wien, Inv. No. 187.553 a, b, c, d. Photo: Alex Rosoli.

KHM mit MVK und OTM. designer Shade Thomas-Fahm. She was the first Nigerian to open a boutique with her own
collection in the 1960s, developing a characteristic Nigerian style in her reinterpretation of international fashion trends using locally produced fabrics. A comparable approach defines the vibrant fashion scene in Nigeria to this day. Shade-Fahm, who is now a celebrity remains a vehement critic of the use of expensive imported lace, and fuelled by her national pride, she exclusively uses locally produced textiles in her fashion lines. ${ }^{27}$ She also claims to have introduced embroidery in Nigerian women's fashions. Inspired by the embroidery on the men's agbada robes, in the late 1960s she developed women's blouses and kaftans with the neckline edged with machine chain stitch embroidery (Thomas-Fahm 2004). In the late 1970s, an aso oke style evolved evoking the aesthetics of industrial embroideries, copying them with machine chain stitch motifs on hand-woven narrow strips.

Regardless of these developments, imported embroideries remained extremely popular in Nigeria. They asserted themselves as an essential component of neo-traditional dress in Southern Nigeria and as a decisive element of its economy of prestige.

Despite the import ban, embroidery exports from Austria reached a peak in 1982. Deliveries were made to the Republic of Benin, but the fabric still found its way from there to Nigeria. During the heyday, 1,400 embroidery machines in Vorarlberg worked 
throughout, with some commissions outsourced abroad in order to satisfy the enormous demand. ${ }^{28}$

The first major decline in embroidery exports occurred with the naira devaluation in 1984. As a consequence this weakened the wholesale trade and increased small-scale imports. However, a decisive factor for the change in the market structure was the reorganization of the flow of funds to Austria for payment for the goods. With the import ban, the flow of foreign exchange out of the country was also curtailed, and financial transactions became more difficult. Although the Austrian embroidery agents initially functioned as their own money couriers, this became increasingly dangerous, since - as described above - it could lead to arrest with a lengthy prison sentence. Money transfer was therefore ceded to the Nigerian business partners, finally leading to the break-up of the monopoly of major importers as contacts and insider information was spread. This development also resulted in diversification in Lustenau since the higher frequency of visits by businesswomen from Nigeria enabled small embroidery companies who had worked on commission and never sent agents to Nigeria to reach out directly to new customers. ${ }^{29}$

In the golden age of the African lace business in Nigeria, Austrians were the market leaders. Swiss firms only started with specific production targeted at Nigeria around the mid-1970s. The company Filtex, for example, which to this day serves the high-ticket and quality sector of the Nigerian market, did not start doing business in Africa until 1980. ${ }^{30}$

Embroidery exports reached an all-time low in 1989-90 as a result of the drop in crude oil prices. Consequently, numerous small businesses in Lustenau had to close their doors. From 1,389 embroidery machines in Vorarlberg, only 506 were still operating in 1993 (Murorunkwere 2002: 44).

\section{Development of Designs}

In Vorarlberg and Switzerland, the designs for the embroideries are created by specialized designers. Their training covers both technical knowledge about the production process and creative pattern development. Producer and patron are both equally involved in the design process, as the manufacturers in Vorarlberg and Switzerland identify trends through exchange with their Nigerian customers and following their advice. This information is then passed on to the designers, either as a suggestion or a requirement. What John Picton was able to determine based on his research on the origins of patterns of wax-print textiles in Great Britain applies in equal measure to lace textiles: "and it is evident from their various archives, firstly that these developments were contingent upon a local agency with a far greater determining role than has hitherto been realised, and secondly that the employees of these firms are kept in employment by African patronage" (Picton 1995: 25). Unlike research on the history of wax prints, which is limited to the information contained in archives, with the embroidery industry it was still possible to interview contemporary witnesses about how the special aesthetic of African lace evolved.

50 As previously mentioned, the use of lace in Nigeria began with white ladies' blouses out of eyelet embroidery or guipure lace and dates back to the colonial era. At that time no specific production for Africa existed: the same goods sold in Europe were traded to Nigeria. This so-called "whitework" had been fabricated by European embroidery firms 
primarily in Switzerland, in Austria (Vorarlberg), and Italy since the 19th century. As a result of this tradition the factories could rely on a pattern collection that had been expanded and developed for decades and that was used for women's and children's fashions, for underwear, and also for household textiles. It was actually such samples from the traditional assortment that the first Vorarlberg embroiderers travelling to Nigeria offered for sale there. However, they very soon started developing new product lines as they interacted with local importers.

\section{Sample book with whitework embroidery}

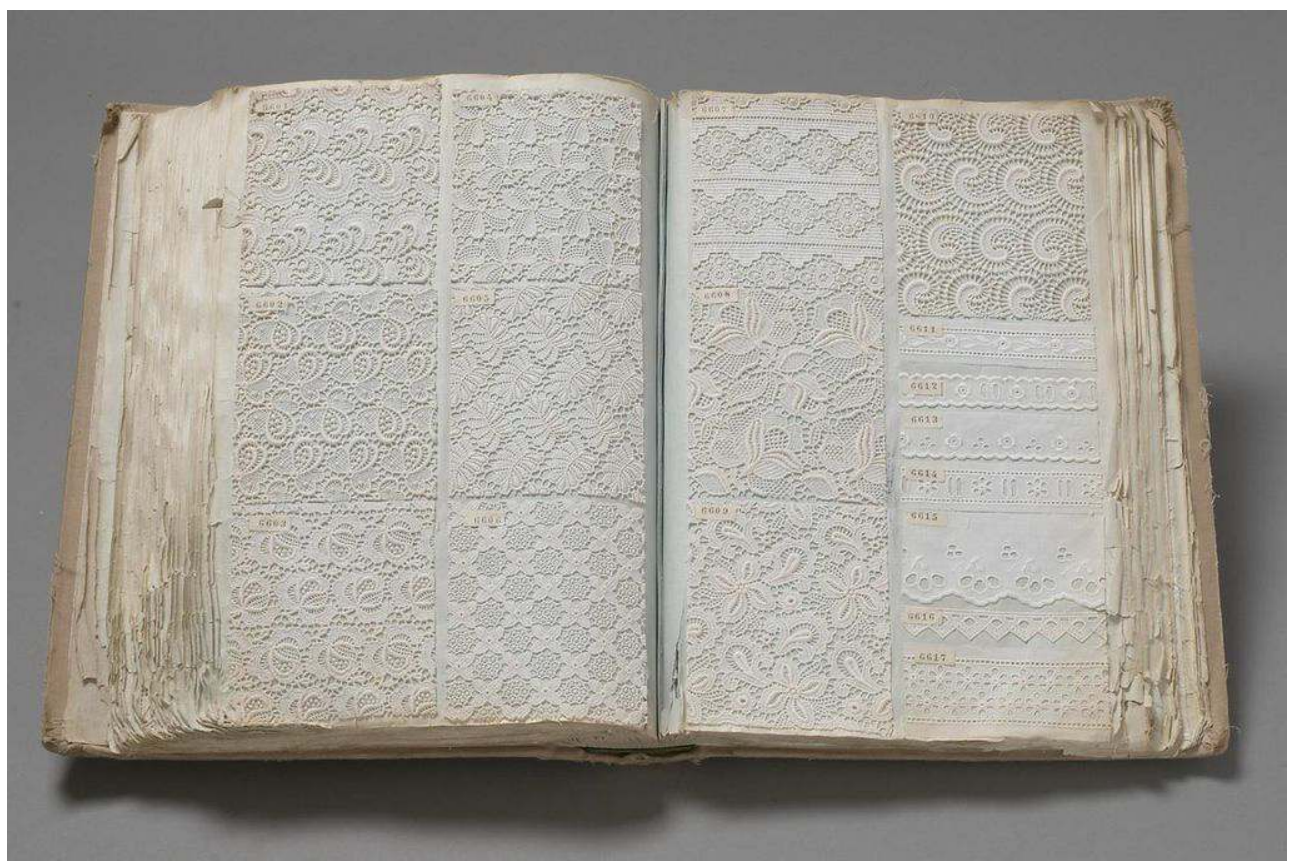

Lustenau, Austriaearly 20th century K. Riedesser company, Lustenau. Photo: Alex Rosoli.

KHм MIT MVK UND ÖTM.

51 In the beginning, they simply adapted the usual patterns of European whitework, by enlarging them and by producing coarser versions. To this day, the whitework patterns represent an important source of inspiration and are used time and again for African lace in a multiplicity of variations. This also explains the different aesthetic from the wax prints, as in the embroideries floral motifs, paisley shapes, and abstract patterns abound that are quite distinct from the textile patterns otherwise common in Africa; these tend to be multicoloured, large-format, and often figurative motifs. Embroidery patterns by contrast are normally small-sized and rarely occur in large renderings. The main reason for this is the cost of production, as the machine embroidery of large motifs is more expensive than the production of small-format patterns. Colour ways are also markedly different from those usual for the printed cotton textiles otherwise so popular in West Africa and from hand-woven textiles, which are normally extremely colourful. By contrast, the costly lace textiles are preferred in subdued tones, the so-called "cool" colours that are considered in Nigeria to be more classic and long-lasting.

Initially, in the early 1960s, white all-over eyelet embroidery was the main product sold in Nigeria, but soon it also became available in various pastel colours. ${ }^{31}$ According to Shitu, in about 1967 in addition to these plain laces, companies started producing bicoloured textiles. At his suggestion, fabrics in various base colours were embroidered with yarn in 
a different colour. He first selected patterns used for blouse fronts and suggested replicating these. These first bicoloured textiles were not embroidered all over, however, but rather had the appearance of assembled borders. In the 1960s, Austrian companies used sturdy cotton as their base material: first cambric and then sateen. The light, finer cotton voile fabrics still used today were not introduced until the 1970s.

In the early 1970s, heavy, multicoloured eyelet embroidery textiles came into fashion; their main feature was different colours aligned vertically, often resulting in a wave-like pattern along the length of the fabric. This feature also resulted from the production technique, because the needles only had to be threaded once, and the ground pattern of the all-over embroidery remained the same for the entire fabric. Because of the stitch density, this type of embroidery was expensive. With its lively pastel colours it set the tone for fashion in the early 1970s in Nigeria. The fact that many of the stars of Juju music chose to have their stage outfits tailored from this material gives further evidence of the popularity of these fabrics.

A defining characteristic of lace clothes for women and men in the 1970s was short sleeves. It was not until the 1980s that long-sleeved blouses and shirts common to this day gained a foothold. In the 1970s, three ladies' outfits could be tailored from ten yards of material, while men needed seven and a half yards for a complete ensemble of an agbada gown with shirt and trousers. In the stores, consequently, embroidered fabrics were offered in these lengths. However, this involved a loss for the retailers, because they always had fabric remnants, as they were supplied from the factories in lengths of ten or fifteen yards. From the mid-1980s on, the fabric was sold exclusively in lengths of five or ten yards.

55 In the early 1970s the yarn used for eyelet embroidery was mercerized cotton, while today primarily rayon is utilized. In the mid-1970s, looser embroidered cotton voile fabrics with large hand-cut perforations came into fashion. These textiles, called "handcut" or "air condition", were much lighter, but allowed seductive "insights" that were criticized as being immoral in Nigeria. ${ }^{32}$ During the era of the oil boom, materials with fancy figurative motifs became popular and were produced in large quantities. In addition to the previously typical floral patterns, the motifs now embraced animals, fruit, and everyday objects, as well as prestige items such as high-heeled shoes, watches, logos of expensive car brands, plus those of airlines, all the way to dollar bills. These fancy textiles, also dubbed "letter fabrics" in Lustenau, were mainly crafted from cheap cotton weaves with loose stitching, and astonishing quantities of them were sold. At the end of the 1970s, the so-called "etching boom" occurred when heavy guipure fabrics became particularly popular. They were extremely costly because of the elaborate production process and the large amount of yarn used. A women's ensemble made of this material with a multicoloured complex pattern could cost up to 1,800 euros.

In the 1970s, producers started adding another effect to the fabric by applying Swarovski crystals. Initially, these stones were affixed to the material with metal claws. Later, after the firm Swarovski had developed a new technique, the stones could be bonded to the fabric with adhesive and smaller stones could now be used.

Fabrics with rhinestones are an essential feature of African lace to this day. In contrast to the 1970s, when the stones were integrated into motifs, functioning, for example, as the headlights of embroidered car motifs, the eyes of animals, or the centres of flowers, today they are sprinkled loosely over the fabric, without regard for the embroidered pattern. Along with the density of the stitching and the quality of the base material, the number of 
stones dictates the price. On average today at least 150 to 400 stones are affixed to a tenyard piece of fabric; it may even be as many as up to 1,500 for the North American market and the expatriate Nigerians who are the customers there.

In the 1980s, lurex embroidery came into fashion, and polyester satin was a popular base material, sometimes with application embroideries. All-over embroidered cotton voile textiles gradually gained a foothold in the market and have remained popular to this day. Only the colour combinations and embroidery patterns have changed since the 1990s. In the 1990s, vibrant colours were popular, while today more muted colours are preferred. As mentioned above, in the mid-1970s embroidered organza was introduced by the company HOH. When their General Manager travelled to Nigeria for the first time in 1975, he took some of their "Arabian" samples with him, i.e. organza with applied, hand-cut flowers and stones. After he showed his materials to importer Obebe, she was excited by the "Arabian" organza and placed a first order. Silk or the more common polyester organza are sheer fabrics that are generally used as a base for sequin embroidery. Embroidered organza gained a wider market presence around the late 1990s and is now extremely fashionable for ladies' wear. Initially, only a single layer of fabric was embroidered, whereas now double organza, i.e. two layers, is more common. The doubling gives the end product more stiffness, which is especially desirable.

Although colour trends and ideas of patterns, colour combinations, and materials are conveyed or requested by the Nigerian business partners, giving them a critical role in the development of the embroideries both in the past and the present, the actual pattern designers reside in Vorarlberg and Switzerland. The factories in Nigeria also ordered their patterns from these designers. The remembrances of Helmut Ritter in Lustenau are particularly illuminating. He was one of the designers who created the first "Africa patterns" for Lustima and designed literally thousands of fabrics during the heyday of the business. He claims that when he started working for this market, his clients did not brief him with clear instructions on the kind of patterns they wanted. He had never seen African fabrics himself or received any for inspiration and had never been to Africa. When he started creating designs for the newly acquired Nigerian market in the 1960s, he simply came up with patterns himself that he thought would work. He started out using whitework patterns and adapted paisley shapes in larger formats. Another motif that he elaborated into a variety of versions was an oval, called the egg design in Nigeria, which became a bestseller and was issued by a number of companies based on patterns drawn from various designers. He drew his inspiration from a personal pattern archive and his imagination. On this basis and with the help of suggestions by his clients, he created countless patterns, but never studied African culture, textiles, or iconography.

In the mid-1970s, on the basis of his own intuition Ritter developed a design featuring an apple, laying the foundation for the fancy motifs mentioned above. Initially no one wanted to embroider the apple pattern, but he finally persuaded Kurt Nachbauer from Lustima, who then achieved sweeping success with the design. The other early patterns were scissors, a cat, an umbrella, and finally the Mercedes star. The unique feature of this innovation was that all these motifs were incorporated in standard abstract pattern formations used for embroideries and not randomly spread over the fabric. Soon other designers and embroiderers adopted this idea, and mass production that was to last several years got underway. An anecdote recounted by Ritter's son Christof, who has since taken over his father's business, illustrates the difficulty in channelling creative energy during the boom time to continually come up with novelties for a multifaceted 
clientele. His father supposedly asked his children for ideas, and one design that resulted was a pen with inkpot. In the evening, the children often prayed that the customers would pay and that their father would have good ideas.

Whereas in the European and American fashion business, trend agencies define certain seasonal colours and fashion themes, upon which textile producers then base their collections, trend scouting does not really exist for the African market. The common practice is still to simply try out what might prove successful - a method essentially based on trial and error. Decisions are made based on instinct, not on market research.

Major Nigerian importers who are considered to have a good sense of fashion continue to exercise significant influence. Their advice and suggestions are willingly accepted and put into practice, as it is after all precisely these businesswomen and their customers who set the fashion when they attend major events where they are photographed and thereafter appear in society and fashion journals. Embroidered textiles have often set a trend when worn as an aso ebi to a party hosted by an influential Lagosian family. Today it is primarily society magazines such as Ovation in which these events and the wardrobes of the rich and beautiful are documented, so fashions are now launched through the media. International events also play a role. For example, the yellow lace suit that Michelle Obama wore to the inauguration of her husband prompted increased demand for guipure fabrics in pastel colours; in Lustenau and Lagos this was called the Obama effect.

While during the boom, when Ritter Senior was active, the principle anything goes applied, and almost anything could be sold, today the situation appears radically different. Members of the actual designer generation such as his son first of all have to take account of production costs in their designs and must develop them based on the cost factor of stitch density combined with the amount of material. In other words, they must be artist and technician at the same time. In the past the quality of the fabrics was better, the stitch density was higher, and yarn size was finer: "Before, it used to be like a copper engraving, precisely embroidered with ancient machines and fine yarn." ${ }^{33}$ Patterns today are more sophisticated, but in the 1970s their execution was more refined.

The purchasing power of Nigerian customers has declined in the last two decades, and competition from the Chinese, Korean, and Indian embroidery industries has increased. Despite all this, producers in Vorarlberg and Switzerland still thrive because of the high standard of their products, the particularly fine finishing, and above all their continual innovation and their sophisticated designs. Only a few larger firms employ their own designers; most manufacturers purchase their patterns from freelance designers. These designers maintain their anonymity, and companies do not like to reveal from whom they buy their patterns. The sale agents in the lace companies normally decide which designs should be generated, then they brief the designers regarding how much the fabric can cost in production, whether they want a floral, ornamental, or graphic motif, what the base material for the embroidery should be, and what technique will be used (e.g., allover embroidery, guipure, sequin or cord lace). Sometimes they bring materials from Nigeria for inspiration. The designers also suggest different colour combinations with each design and present up to twenty new creations at a time from which their patron can choose. Sometimes negotiations are also conducted with major Nigerian customers, who give feedback on the designs and offer suggestions. A designer creates around 3,000 patterns a year. 


\section{Trade Structure in and around Lustenau}

65

At the beginning of this transcontinental business relationship, Nigerian importers flew from Nigeria to Zurich, where they continued their journey overland to Lustenau, stopping off in St Gallen. Producers from Vorarlberg would send employees to Zurich to meet the arriving flights from Lagos, pick up the merchants, and transfer them to the companies in Lustenau. From the outset the embroiderers played an active role in the transportation of their Nigerian customers, and functioning on the basis of a gentleman's agreement they drove and still drive the guests from one company to another. Formerly the companies in general received no notification of the arrival of the traders; they simply ventured to Zurich airport to pick up all those who arrived. A major trader in Lagos who has been in the business for many years told the story of how on her very first business trip in 1972 she just flew to Zurich without having had any contact with embroidery companies before. She was picked up at the airport by an employee of an Austrian lace firm and taken to Lustenau. One of her sisters, who had been importing embroideries for some time, had explained the procedure to her. ${ }^{34}$ Since 1978, the taxi firm Mama Bush has been taking care of the airport transfer of Nigerian merchants to Lustenau. The owner, Traudl Bösch, originally worked in the embroidery sector herself and then specialized in the transportation needs of Nigerian customers. The visa requirements of the Schengen region also affect the travel plans of the Nigerian clientele. Today, some of the women who have both a British visa and a Schengen visa travel first to London and from there take a cheap flight with Ryanair to Friedrichshafen on Lake Constance..$^{35}$ Others take advantage of another major connection, with Lufthansa, which offers daily flights from Abuja and Lagos to Frankfurt and flies direct to Friedrichshafen. After Switzerland became part of the Schengen area, some of the women traders began to fly direct to Zurich, do their business in St Gallen and St Margarethen in Switzerland and then continue to Lustenau. Mama Bush provides transportation for both routes.

Mama Bush now receives calls direct from Nigeria with pick-up requests for the relevant airport; the drivers take the women from one business to the other, drive them to dinner at a restaurant, and if necessary help out with customs, with the check-in, or other necessities. Traudl Bösch has maintained a friendly business relationship with Nigerian merchants for several decades, and has even been invited to weddings in Nigeria. Today, the company owns three vehicles, which are actually minivans (an old limousine that seats eight is rarely used now), and in addition to the owner there are two drivers. The business offers shared taxi travel and there is a fixed price for the trip, which is divided among the passengers. The Nigerian customers greatly appreciate the long-term experience, her understanding of their needs and the special service offered by Mama Bush. She knows all the companies and their sales representatives responsible for the African market. They are normally known by their first name only; on arrival one can simply say "I would like to see Mary, Chief Blaser, Margret, Charlie" or such like and will reach the desired destination and the companies dotted about the extensive area of Lustenau without having to give an address or further information. Mama Bush's team also knows the hotels where the traders normally stay and the Chinese restaurants where they like to eat, and can take inexperienced women straight to the right place. The drivers are also familiar with the visitors' buying habits and the relevant trends. For example, a Bush employee defines three categories of Austrian embroidery companies: 
those that traders always visit to see what is available, but where they do not necessarily buy anything; those that are in vogue at the moment and where purchases are made regardless of the price; and those that offer especially favourably priced merchandise.

During their stay, which usually lasts three to five days, the Nigerian businesswomen visit several companies, buy an assortment of goods, and place additional orders. They make intensive use of their time in Lustenau, which is very strenuous; they have to flip through hundreds of patterns, negotiate with sales representatives, and make calculations. The success of their business depends on their choices, and with these expensive products, a mistake can lead to large financial losses. The textiles are shipped direct by the lace companies.

Local companies specialized in shipping to Africa play an important role in the trade network. Here again there are firms and above all employees who have been organizing the shipping of Austrian embroideries to Nigeria for decades; they have special insider knowledge and are well aware of the relevant trade, customs, and import requirements. Over the decades, a system has been established both in Nigeria and in Lustenau that deals creatively with difficulties such as import bans and increased customs duties. At each end of the transportation system are key individuals with critical networks and skills that are vital to the business. Here too, personal business contacts have existed for decades.

When the export to Nigeria was no longer possible following the import ban in 1977, as mentioned above the goods were shipped to the neighbouring Republic of Benin and were forwarded from there overland to their actual destination. Regardless of these difficulties, the years between 1977 and 1982 were the best both for the Austrian embroidery companies and for the shippers. ${ }^{36}$ During that time, major importers who in fact profited exclusively from trade with Nigeria set up shop in Cotonou. Very little African lace was in fact sold in the Republic of Benin itself. Today, without exception, the merchandise is shipped by airfreight to Nigeria. Customers in Lagos can reckon on receiving the finished goods at the latest 10 to 14 days after placing a phone order, even if the fabrics still have to be manufactured in Lustenau.

70 In all aspects, business with Nigeria is based on mutual trust and a handshake; written agreements or orders remain rare. Adhering to the rules of the game is a matter of honour. With many orders, prepayment is expected, but large quantities are also shipped immediately on receipt of a telephone order, if long-term business relations exist with the customer. Producers regularly travel to Lagos to present new collections, maintain good relations with their customers, and for administrative and accounting purposes.

71 Just as with the clothing industry, the Vorarlberg embroidery industry's relationship with Nigeria is threatened by competition from lower-priced goods from the Asian textile industry. In addition, restrictive entry requirements due to Schengen visa regulations represent a further obstacle to trade contacts. Some embroidery producers are complaining about the excessive bureaucracy of helping their customers obtain a visa in Nigeria also on the Austrian end, which has become difficult to handle for small firms. In addition, it happens time and again that long-standing customers are refused a visa, even though the embroidery company provides the necessary assurances. The problem escalated a few years ago when as a result of a previous visa scandal in 2006, the Republic of Austria pronounced a ban on travellers entering the country from Nigeria. There were desperate reactions from Vorarlberg embroidery industrialists, who feared that their biggest market would disappear if their business associates were no longer permitted to 
enter the country (Jurkowitsch and Sarlay 2009). ${ }^{37}$ It is therefore not surprising that to an increasing extent Nigerian businesswomen now travel to China or India, or make their purchases in the rising trading centre of Dubai, where they can travel to freely without restrictions. $^{38}$

\section{The Trade in Nigeria}

Lagos is currently the centre of the African lace trade, and it is here that merchants from other parts of the country buy their stock. In the 1970s and early 1980s Ibadan was also an important market for imported embroideries; today, however, it has lost its significance and became irrelevant as far as Austrian goods are concerned, as lace from China dominates the market there. In the 1970s, Austrian sales representatives visited Ibadan regularly and offered their products on Lebanon Street. Kano was another major trading centre, but it is now primarily a market for damask. In recent years, however, Austrian embroidery manufacturers have been trying to gain a foothold in the north of the country again and aim to diversify the market through direct contacts in Abuja or by winning new customers in Ghana.

The embroidery trade in Nigeria is now almost exclusively in the hands of women; they are predominantly Yoruba, with a noticeably high proportion of Ijebu women from what is now Osun State. This was also the region where several Nigerian embroidery factories that are now closed were based, like the Austro-Nigerian Embroidery Factories Ltd in Aiyepe, Ijebu, or Shokas. This region, called Jabu by the Portuguese, was already mentioned in 16th-century European reports as a major weaving centre from which textiles were exported all over West Africa (Law 1986).

The largest concentration of embroideries is to be found for sale at the heart of Lagos Island at the market around Balogun Street and the Moshe Alashi, the central mosque. Behind it lies the so-called Gutter, where at the end of the 1960s the trade started on Kosoko Street when the first specialized shops opened. This market area is still reserved for the embroidery trade, but only a few of the longest-established shops remain there; many have moved to other parts of Lagos or now run the original shop only as a branch.

Overall the textile market area is divided into sectors defined by the different textile categories. Apart from lace, there are areas for ankara, printed cottons which in turn are subdivided into spaces and stores for wax prints or the so-called fancy or java prints; for adire textiles, which are Nigerian fabrics patterned with resist-dye techniques and for which the ground material is usually damask cotton; areas for hand-woven aso oke textiles; and for imported Indian fabrics such as george. There are also areas reserved for European-style textiles and for braids, sewing accessories, "real" lace, etc. Each area of the market has specialized dealers, its own import structure and trade networks. Some ankara textiles for example are made in the country, while others are imported from Ghana, the Ivory Coast, or the Netherlands. Today, Iseyin and Ilorin are the centres for aso oke production, and adire originates primarily from Abeokuta.

Embroideries are offered on different market levels. Street dealers sell cheap Chinese goods on the pavements around Moshe Alashi, stacking them directly on the ground and attracting the attention of passers-by by holding up lengths of fabric. Lining the street, larger shops offer goods of varying quality, usually placing the cheap merchandise in their entrance areas and the better-quality, expensive material inside the shop. In the 
narrow market streets, the stores are aligned closely side by side. The spaces are smaller, but the product range remains the same.

Other Lagos markets also have reserved areas for African lace. Very popular at present is the Alade Market near Opebi Road in Ikeja, which has established itself as a kind of fashion mile on the mainland of Lagos. The upmarket lace shops in the city, Nikky and Oyeog, are located there and serve a sophisticated clientele. Several major shops can be found in Surulere, a middle-class district. Extremely exclusive shops in affluent residential areas are known only to insiders. A well-known boutique of this kind, for instance, is not recognizable as such from the outside, is situated in a well-kept home in Yaba in Lagos, and is accessed by passing through a courtyard beautifully decorated with plants. The small sales area on the ground floor is furnished with glass-fronted wooden showcases in which the exquisite fabrics are displayed. It is unlikely that a visitor would find anything priced at less than 200 euros here. The room is dominated by two sofas where the high-end customers can sit in comfort while salesgirls show them the fabrics of their choice. The main duty of these attendants is unfolding the fabrics and putting them tidily away again. The fabrics are stored on the upper floor, where only special customers may browse through the stock. All other clients must describe the colours and quality they are looking for, and suitable fabrics are then fetched from upstairs. Unique, very fine, and high-priced embroideries are only brought down when specially requested and are not on display.

The style of presentation of the embroidery fabrics in the specialized shops is noteworthy. It differs markedly from the display of ankara fabrics, the various categories of printed cottons, which are stacked on shelfs or hung over rods for display. The embroideries are folded in the same way as the printed textiles, but in contrast they are packaged in a transparent plastic wrapping. The packages are set upright in glazed, room-height shelving and slightly fanned out, giving the impression of a fabric library behind glass. A wooden slat placed in the fold of the fabric stabilizes the packages to make them stand up. This display clearly signals the exquisiteness of the expensive fabrics. While new shops seem to prefer wooden showcases, the older ones, and the small stores in the central market on Lagos Island try to achieve a glamorous effect with the abundant use of mirrors on the ceiling and walls and by framing the glass showcases with mirror tiles. Both styles create an atmosphere of elegance and tranquillity to do justice to the luxurious fabrics.

Other elegant shops, around Opebi Street or Allen Avenue, also carry Italian shoes and bags that are selected and ordered by the owners on visits to Italy. Some merchants carry gold-plated costume jewellery or other accessories from their shopping tours, for instance from London, and offer these in their market stores along with the embroideries. The customers are mostly female, but there are also men who favour selecting the fabrics for their clothes themselves. During the sales discussions and the choice making other customers or chance visitors to the shop join in, to give suggestions and share their own experiences and views of current trends.

In Nigeria it is quite popular to shop at work, thus avoiding the hectic markets, crowds, heat, and the unbearable traffic. Normally there is at least one person in a workplace who trades informally and who frequently specializes in a specific kind of textile; these people will regularly bring in novelties and also take orders. More than a few successful businesswomen have profited from providing this convenience to their colleagues, thereby laying the foundation for a flourishing business. One of the best-known 
embroidery merchants at present, Mrs Adeniyi Usman, wholesale importer and owner of the elegant lace boutique Oyeog, started her career as a secretary at a bank. She started in 1986 and before long, was selling piqué cotton and polished cotton fabrics from Switzerland. She found customers at work and also used her private flat as a salesroom. Every three weeks she travelled to Switzerland to stock up on goods, and gradually expanded her assortment until she specialized in embroideries. After about 4 years, she opened her first shop and has been a successful textile retailer for more than 25 years. ${ }^{39}$ The founder of SAS (Sola Adediji Stores), one of the most popular shops in Surulere with a branch in Ikoji, also started out selling lace in offices. She finally opened her own shop, which is now run by her two daughters. Women who travel regularly to Austria or Switzerland and sell embroidered textiles to their extended circle of acquaintances as a secondary business continue to account for a significant percentage of the whole export volume to Nigeria and represent a substantial group of customers for the industry.

\section{The Current Market and Range of Products}

Nigeria is still the most important market for embroideries manufactured in Vorarlberg. The centre of production lies in Lustenau, while in St Gallen in Switzerland only two factories are still in the African lace business. In Vorarlberg, 205 embroidery companies employing about 400 machines currently export 98 per cent of their production, most of which goes to Nigeria. Some firms cater exclusively to this West African market, while others also serve the underwear industry and the international fashion market. Almost no textiles for home decoration are produced any longer; they are now mainly manufactured in Turkey or East Asia.

At present, the African lace industry in Vorarlberg is facing a crisis due to the poor state of the world economy. Compared to the previous year, exports to Nigeria fell by 50 per cent in 2009. The percentage of total exports to West Africa accounted for by African lace in 2009 was 48 per cent; in 2008 it was 56 per cent. ${ }^{40}$

Production is getting increasingly difficult. There is now just one company left in Vorarlberg for textile finishing, which gives the fabrics their particularly fine soft surface that is a signature feature of Austrian products. The cotton base material is generally purchased from India, and the rayon embroidery yarn comes from Turkey. In the past, cotton voile was bought primarily from Switzerland. Swiss voile is still considered the first-class material and, as one embroiderer reckoned, it could be compared with cashmere in terms of quality. For a long time, Chinese and Korean producers were unable to acquire cotton voile; their fabrics were embroidered on polyester voile with polyester thread, and were therefore unable to compete with the Swiss and Austrian products. Today, their textiles can hardly be distinguished from the European ones. The real cachet that the Austrians and Swiss have been able to maintain lies in the fabric processing, the fine finishing, and strict quality control. Every completed panel of fabric is carefully checked, and flaws are corrected by hand. This considerable effort increases the costs and makes the end product correspondingly more expensive.

The fabrics are generally packaged in ten-yard lengths $(9.2 \mathrm{~m})$, in coupons or coups, also called bundles in Nigeria. ${ }^{41}$ The embroidery machines were traditionally geared to process a length of ten yards; modern equipment can also produce fifteen-yard lengths, and in large facilities especially in Asia and Turkey thirty-yard machines are also in use. 
The embroidery patterns are fed in via computer, with some older machines using punch cards.

The embroideries are in general made to order and the companies display only a limited range of goods in their showrooms. Some firms sell exclusively in Lustenau itself to dropin customers or fulfil orders for regular customers. Sales representatives for other embroidery companies travel to Nigeria on average every 3 months to present their new collections, which depending on the company include between 30 and 150 patterns on each visit. Depending on its size, an Austrian manufacturer brings out 60 to over 400 new designs a year. Innovation is essential to survival, since designs are quickly copied by Asian producers; thereafter these better-quality products can no longer be sold at their original prices.

The trips made by Austrian embroiderers to Nigeria take the same form on each visit. The representative usually stays for one week and spends the entire time in Lagos. They always reside at the same large business hotel. Each of them ${ }^{42}$ receives customers in their hotel room, where they present the new patterns, take orders, and conduct negotiations. The week is extremely busy and exhausting. On arrival, the representatives immediately phone up to 300 businesswomen to arrange appointments, which then take place daily from the early morning into the late evening. Before departure, the embroiderers schedule visits to markets to see what is being offered, visit retailers at their shops, and exchange news.

Every embroidery company has its speciality or its own signature feature that insiders recognize immediately; the textiles themselves are not marked. Some producers are valued for their detailed floral motifs, and others for their colourful geometric designs in multiple colour ways; others specialize in sequin embroidery, and yet others in cord lace. Some firms are known for their "men's fabrics". At present, the most important products are all-over embroidery on fine cotton voile and embroidery on double polyester organza, often with sequin embroidery, fine eyelet embroidery (broderie anglaise) and to a lesser extent guipure lace. Hand-cut and application embroideries are less in demand. An essential feature of all the fabrics are the decorative scallops along both sides of the cloth needed for sleeves, seams, and décolleté; another must are Swarovski crystals applied in regular intervals over the fabric. One recent innovation is pearls sprinkled over the pattern and affixed to the fabric, further emphasizing the relief structure of the embroidery.

Men's fabrics are generally in muted colours and tone in tone embroidery, such as white, ivory, sky or powder blue, "choco choco", beige/"carton colour", grey, pastel yellow, or mint. In Nigeria, these colours are considered as cool, soft, or muted in contrast to the loud colours favoured by the ladies. In women's fabrics, demand is currently strong for baby pink, brown tones, orange, apricot/peach, yellow, lilac, turquoise, pale green, and also lurex embroidery. The textiles are embroidered less densely than in the 1980s and 1990s. It is important to maintain a good ratio between base material and embroidery, because if too much material is visible, the fabric is considered "too open", and too much pattern is considered "too busy". ${ }^{43}$

Today the minimum order per pattern and colour way is two to three coupons, whereas a decade ago the minimum accepted was six to ten coupons. Back then, an average order comprised twenty coupons per colour and design. Nowadays, the Nigerian importers avoid risk and overstocking. They prefer to place follow-up orders if needed. Normally retailers don't make sales, some stock old fabrics for decades in the hope of being able to 
sell them one day. The "party business" for aso $e \mathrm{ebi}^{44}$ is very important because in this case orders are placed for large quantities of a single pattern, sometimes up to several hundred pieces.

During the heyday of the embroidery trade at the end of the 1970s, more than 100,000 coupons were sold of certain patterns, but such numbers are no longer achieved today. At the time, the egg, clock, and penny designs were a real sales hit. A single pattern could sell successfully for several years, and individual importers had a monopoly on certain patterns. In the 1970s, some fabrics had names in Nigeria, but with the variety of patterns and constant innovations today, this has been abandoned. The fabrics were named after personalities who attracted public attention to a certain fabric, or by association, such as Wonyosi or Aircondition. For example, the Atiku popular with men for their trouser and shirt ensembles is a cotton fabric with structured weaving. The embroidery companies that offer it in their assortment commission these fabrics from specialized factories, for example in Switzerland or in East Germany. The style bears the name of former vicepresident Abubakar Atiku (1999 to 2007), who made it popular.

\section{Men's suit, Nigeria}

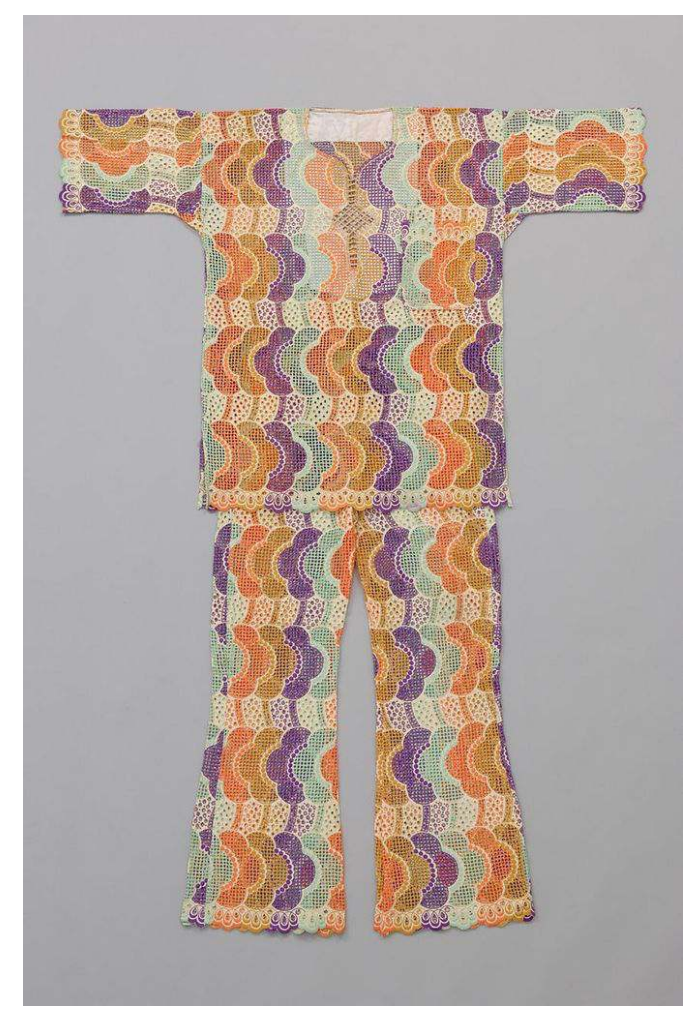

early 1970s. Cotton fabric with industrial eyelet embroidery, Buba shirt: L. $78.5 \mathrm{~cm}$, sokoto pants: L. 107 cm Museum für Völkerkunde Wien, Inv. No. 187.530. Photo: Alex Rosoli.

KHM MIT MVK UND ÖTM.

The designations current today refer to the quality and style of the fabric and are sometimes fancified technical terms that have become familiar terminology in the business. Many of the women traders give the fabrics names based on the motifs they see in the patterns; they like to use names such as cube, umbrella, leaf, hand, figure of eight, half-moon, ball, finger, zig zag, and such like, as they can memorize these more easily than the design numbers. 
est in and demand for African lace in Nigeria remains strong, and the popularity of these kinds of fabrics is often evoked in the media. However, many Nigerians can no longer afford the expensive fabrics. As a consequence some Vorarlberg suppliers have now diversified their product range with the above-mentioned Atiku fabrics or damask, called Guinea brocade in Nigeria, which is in great demand at present. The popularity of lace has caused other textiles to appear on the market that imitate the aesthetic of lace. So, printed cottons with a lace look are fashionable and sold under the brand names Opulent Lace or Opulent Embroideries, and can be purchased for a tenth of the price of real embroideries. In a completely new version of single-face Java prints, a specialized shop in London recently started selling prints with stamped-out holes, imitating hand-cut lace. ${ }^{45}$ Another novelty, discovered in Lagos, was fine damask fabrics in pastel tones, dyed using resist-dye technique, with lace-like patterns, and the special feature of shimmering glass stones affixed to the fabric. A well-known Lagos merchant sells this fabric as "adire with stones", which is in vogue with high society ladies; she has it exclusively manufactured in Senegal.

Lace has become an imminent part of tradition in Nigeria. It is without question an authentic Nigerian material, one that at the same time is traditional and contemporary, African and European. In reflecting upon the significance of imported fabrics for Nigerian fashion, Toyin Odulate summarizes this fact: "It appears Nigeria, and many parts of fashion-savvy Africa, have taken over other people's inventions (fabrics), improved on them and re-presented them to the world. [...] My view on all this is that Nigerian fashion is not so much about being authentically Nigerian as about improving on other people's ideas and infusing an element of something unique, colourful and sometimes seemingly outrageous, and thereby transforming it into something PROUDLY NIGERIAN" ${ }^{46}$ 


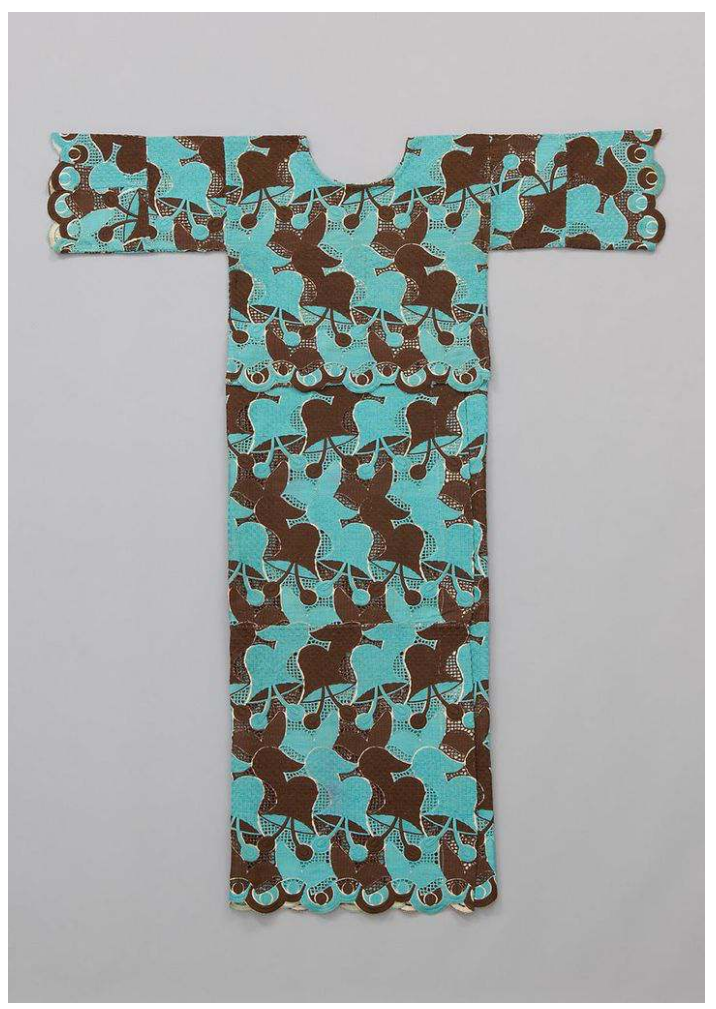

NIgERIA MID-1979S, MUSEUM FÜR VÖLKERKUNDE INV.NO. 188.510. PHOTO: ALEX ROSOLI.

KHM mit MVK und OTM.

\section{BIBLIOGRAPHY}

Apter, Andrew, 2005, The Pan-African Nation. Oil and the Spectacle of Culture in Nigeria. Chicago und London: The University of Chicago Press.

Bender, Wolfgang, 2007, Der nigerianische Highlife. Musik und Kunst in der populären Kultur der 50er und 60er Jahre. Wuppertal: Peter Hammer Verlag.

Beveridge, Fiona C., 1991, Taking Control of Foreign Investment: A Case Study of Indigenisation in Nigeria. The International and Comparative Law Quarterly 40(2): 302-333.

Falola, Toyin und Matthew M. Heaton, 2008, A History of Nigeria. Cambridge: University Press.

Fitz, Ulrich, 1947, Die Vorarlberger Stickereiindustrie und ihr Export. Dissertation. Universität Wien Jurkowitsch, Silke und Alexander Sarlay, 2009, Zukunftspapier zum Projekt „Entdecken von Vorarlberg Stickereien in Westafrika“.Grundlagendokumentation für nachhaltige Wirtschaftsstrategien und Fundament für weitere Projekte. Feldkirch: Wirtschaftskammer Vorarlberger Stickereiwirtschaft. 
Längle, Elisabeth, 2004, Vorarlberg stickt für die Welt. Wien: Verlag Christian Brandstätter.

Law, Robin, 1986, Early European Sources Relating to the Kingdom of Ijebu (1500-1700): A Critical Survey. History in Africa 13: 245-260.

Murorunkwere, Jeanne d'Arc, 2002, Vorarlberger Stickereien unter besonderer Berücksichtigung der Exportbeziehungen zu Afrika. Unpubl. Diss. Graz: Karl-Franzens-Universität.

Picton, John, 1995, Technology, Tradition and Lurex: The Art of Textiles in Africa. In: John Picton (Hg.), The Art of African Textiles. Technology, Tradition and Lurex (London: Lund Humphries Publishers), 9-30.

Plankensteiner, Barbara and Nath Mayo Adediran (Eds.), 2010, African Lace. A History of Trade, Creativity and Fashion in Nigeria. Co-edited with Nath Mayo Adediran. Wien, Gent : Snoeck Publishers.

Plankensteiner, Barbara, 2010, African Lace. Material of a Transcontinental History of Relations, in African Lace pp. 113-151.

Renne, Elisha P., 1997, Traditional Modernity“ and the Economics of Handwoven Cloth Production in Southwestern Nigeria. Economic Development and Cultural Change 45(4): 773-792.

Thomas-Fahm, Shade, 2004, Faces of She. Lagos: Literamed Publications.

\section{NOTES}

1. This article is a slightly altered version of a recently published chapter (Plankensteiner 2010). The original written in German was translated by Andrew Smith.

2. In her detailed and informative book on Vorarlberg embroidery, Elisabeth Längle (2004) devotes a chapter to the production specifically for the Nigerian market. She briefly outlines the history of trade, but does not refer to the Nigerian context.

3. The exhibition was co-curated by the author with Nath Mayo Adediran and was a cooperation of the National Museum of Museums and Monuments Nigeria with the Museum für Völkerkunde in Vienna, Austria (Plankensteiner \& Adediran 2010). In Vienna it was shown from October 21, 2010 to March 24, 2011, at the National Museum in Lagos from June 3, 2011 to January 16, 2012. A further venue in Lustenau, Austria is planned for 2013.

4. Other towns in the Vorarlberg region where the embroidery industry was significant are Altach and Hohenems, among others. However, the number of embroidery machines there was at most a quarter of those in Lustenau. Several embroidery machines were also in use in Wolfurt (Fitz 1947).

5. Written communication, 10.2.2009.

6. I would like to thank Olayemi Afolabi, who kindly obtained this information from Ms Makanju, the older sister of the deceased, and passed it on to me; strictly speaking she was also the one who drew my attention to the importance of Debo Adekoya (1930-96).

7. Personal communication, Oswald Brunner, 3.6.2008.

8. Hundertpfund, written communication, 10.2.2009.

9. Personal communications, Heinz Hundertpfund, Oswald Brunner, Josef Blaser, 2009.

10. In Yoruba, ebun oluwa means "God's gift".

11. The following information is based on two interviews, conducted on 9.4.2009 and 4.12.2009.

12. Nigerian import figures show clearly that from 1967 on Austrian lace gradually forced Italian embroidered textiles out of the market. Market analysis/Nigerian foreign trade with Austria, source: UNO; per 20.3.2009.

13. The following information is based on interviews conducted on 26.11.2009 and 10.12.2009. 
14. Of the 250 textile factories in Nigeria that employed 350,000 workers in the 1980 s, in 2008 only 40 remained, with 30,000 employees. (The Problem with the Textile Industry by Lucky Fiakpa, Adewoole Ajao, George Oji, Charles Onyeekamuo, This Day, 3.2.2008, p. 27.)

15. Gabriel, Omoh and Victor Ahiuma-Young, How Nigerian Textile Failed to Tap into the 31bn US Booming Garment Market. Vanguard. Lagos, 14 April 2008.. http://allafrica.com. Accessed 19.8.2008.

16. Personal communication, Werner Berlinger, 26.2.2009.

17. Daily Sketch 29.3.1977.

18. According to Chief Owolana, an exception was made for six large import companies for another year; she herself, Chief Obebe, and the Shitu brothers were included in this exception. She could not definitely remember the other three.

19. Personal communication, Arno Fitz, 23.9.2009.

20. Trotz Nigeria-Schlappe wird fleißig exportiert (Despite the Nigerian set-back, exports are flourishing). Die Presse 3/4.12.1977.

21. In schwarze Geschäfte verstrickt (Entwined in black market business). Profile no. 31, 2.8.1977; Sticker haben Faden verloren (Lace-makers have lost the thread). Kurier 6.8.1977, p. 3

22. Vorarlberger Nachrichten 31.8.77, p. 22.

23. Daily Times 14.5.77.

24. Daily Times 26.6.77.

25. Daily Times 13.6.77.

26. A Nation of Avaricious Women? Daily Times 3.6.77.

27. Personal communication, Shade Thomas-Fahm, 11.4.2009.

28. Personal communication, Kurt Isele, 23.2.2009.

29. Personal communication, Arno Fitz, 23.9.2009.

30. Personal communication, Arno Fitz, 23.9.2009.

31. The following information about the history of styles in African lace is based on interviews with Helmut Ritter, Josef Blaser, Karl Hagspiel, Mobolaji Shitu, and Oswald Brunner, as well as on analysis of pattern books from the companies Oskar Hämmerle, HKG, Riedesser, and Ernst Bösch.

32. Personal communication, Tam Fiofori, 10.4.2010.

33. Personal communication, Christof Ritter, 26.2.2009.

34. Personal communication, Mrs Modupe L. Olukoja, Modupe Stores, Lagos, 24.11.2009.

35. Since spring 2010 only direct flights from London Stanstead to Memmingen are offered.

36. Personal communication, Kurt Isele, in Lustenau, 23.2.2009.

37. Wirtschaftszeit Online Magazine 13.3.2006.

38. See also Jurkowitsch and Sarlay 2009: $154 \mathrm{f}$.

39. Personal communication, Mrs Adeniyi Usman, 16.4.2010.

40. Andreas Staudacher and Alexandra Schoass (Austrian Federal Economic Chamber Vorarlberg), Export Figures, Association of the Vorarlberg Embroidery Industry for 2008 and 2009.

41. A packed coupon measures $67 \times 25 \mathrm{~cm}$. The fabrics are between 128 and $132 \mathrm{~cm}$ wide.

42. In the early days of exporting to Nigeria, it was usually men who travelled. Today, a number of women have been extremely successful on these trips.

43. Personal communication, Rudolf Bösch, 2008.

44. Aso ebi is a sort of uniform for relatives or groups of people who want to show their solidarity and group coherence by wearing clothes made of the same fabric.

45. The centre of the lace trade in the UK is in the area around Liverpool Street in London. This is where many Nigerians stock up on goods.

46. “Ankara, Damask, Lace and George - Nigerian or not?”, Next 14 February 2009. http://234next.com (accessed 22.2.2009). 


\section{ABSTRACTS}

This article tries to reconstruct how African lace first emerged and developed over the decades. The history of industrial embroideries in Nigeria has so far remained unwritten, and the historical overview here is based on numerous interviews with time witnesses in Nigeria, Austria, and Switzerland. The overview makes no claim to completeness, as far more actors were involved in this history of relations across continents than those whose accounts are summarized here. The research was part of a collaborative exhibition project that aimed to embrace the sociocultural significance of Lace in Nigeria for the first time.

Cet article vise à contextualiser l'apparition de la broderie africaine qui s'est développée depuis fort longue date au Nigeria. L'histoire de la production industrielle de la broderie au Nigeria n'a pas été étudiée et l'approche historique de cette étude est fondée sur de nombreux interviews de témoins de cette époque vivant au Nigéria, en Autriche et en Suisse. Cette présentation ne vise pas à l'exhaustivité tant il y a d'acteurs impliqués dans l'histoire de ces relations intercontinentales qui n'apparaissent pas dans cette présentation.Cette recherche s'inscrit dans le cadre d'un projet d'exposition collaborative qui visait à présenter pour la première fois les implications socio-culturelles de la broderie au Nigeria.

Este artículo se propone reconstruir el surgimiento y desarrollo del bordado africano a lo largo de décadas. La historia de la producción industrial del bordado en Nigeria no ha sido estudiado hasta la fecha, y la aproximación histórica que propone este artículo se basa en numerosas entrevistas con testimonios de la época en Nigeria, Austria y Suiza. Sin embargo, este repaso histórico no tiene vocación de exhaustividad, pues muchos son los actores que forman parte de esta historia de relaciones intercontinentales y que no aparecen en este texto. Esta investigación formó parte de un proyecto de exposición colaborativa que tenía como objetivo presentar por vez primera las significación socio-cultural del bordado en Nigeria.

\section{INDEX}

Mots-clés: Nigeria, broderie, broderie industrielle, commerce transcontinental

Keywords: Lace, industrial embroideries, transcontinental business

Palabras claves: Bordado, Bordado Industrial, Comercio Transcontinental

\section{AUTHOR}

\section{BARBARA PLANKENSTEINER}

Museum für Völkerkunde, Wien 